\title{
Prepare developed democracies for long-run economic slowdowns
}

\author{
Matthew G. Burgess $\mathbb{1}^{1,2,3 凶}$, Amanda R. Carrico $\mathbb{1}^{2}$, Steven D. Gaines ${ }^{4}$, Alessandro Peri ${ }^{3}$ and \\ Steve Vanderheiden ${ }^{2,5}$
}

Developed democracies proliferated over the past two centuries during an unprecedented era of economic growth, which may be ending. Macroeconomic forecasts predict slowing growth throughout the twenty-first century for structural reasons such as ageing populations, shifts from goods to services, slowing innovation, and debt. Long-run effects of COVID-19 and climate change could further slow growth. Some sustainability scientists assert that slower growth, stagnation or de-growth is an environmental imperative, especially in developed countries. Whether slow growth is inevitable or planned, we argue that developed democracies should prepare for additional fiscal and social stress, some of which is already apparent. We call for a 'guided civic revival', including government and civic efforts aimed at reducing inequality, socially integrating diverse populations and building shared identities, increasing economic opportunity for youth, improving return on investment in taxation and public spending, strengthening formal democratic institutions and investing to improve non-economic drivers of subjective well-being.

M odern liberal democracies-with broad economic and political freedom and stability-predominate in today's developed world, but they are a historical anomaly. Before the Industrial Revolutions, there was both little per-capita gross domestic product (GDP) growth and little democracy (Fig. 1a). Since the Industrial Revolutions, most countries have escaped the 'Malthusian trap'-where land productivity growth led to growth in population but not affluence ${ }^{1}$ - and global affluence has increased by more than a factor of ten ${ }^{1,2}$. This unprecedented global growth has temporally coincided with the global proliferation of democracy (Fig. 1a). In the early nineteenth century, less than $1 \%$ of the world's population lived in a democracy, compared with about 55\% today ${ }^{3}$. There is some evidence of bidirectional causality: on average (with some exceptions), open, democratic institutions promote growth ${ }^{4-6}$, and long-run growth and affluence promote the formation of democratic institutions ${ }^{7,8}$. Developed (that is, high-income) democracies have been at the forefront of these trends (Fig. 1b) but now may face the prospect of long-run slowdowns in economic growth in the twenty-first century.

Here, we review the reasons why twenty-first-century economic growth might be slow, discuss potential fiscal and social challenges that slow growth could pose in developed democracies and discuss strategies countries may use to address these challenges. In our discussion, 'slow growth', 'stagnation', or 'de-growth' usually refers to slower, zero or negative long-run growth, respectively, in per-capita GDP, which measures affluence. However, we also discuss GDP growth in the context of fiscal challenges (and in Fig. 2), as GDP is the denominator of the debt-to-GDP ratio, and it is the tax base.

We consider de-growth (in contrast to slow growth and stagnation) to lie mostly beyond the scope of our discussion, since economists consider unintentional de-growth unlikely ${ }^{9}$, and intentional de-growth (which some have called for ${ }^{10}$ ) seems unlikely to gain political traction in democracies ${ }^{11}$.
We focus on developed democracies, because developed countries (most of which are democracies) may reach long-run stagnation first (Fig. 1a, b) and because instability within developed democracies would have significant implications for the international order. Democracies, in general, have brought gains in political, economic and intellectual freedom. These freedoms, coupled with the rule of law, have been critical drivers of growth ${ }^{4,6}$, with few exceptions ${ }^{4}$. Freedoms of thought, speech and assembly have been critical to the creation and dissemination of knowledge-as exemplified by, for instance, 48 of the world's 50 top universities being found in democratic countries ${ }^{12}$. Surveys often find democratic freedoms to be positively related with subjective well-being (see, for example, ref. ${ }^{13}$ ).

Some of the challenges that slow growth or stagnation could pose to developed democracies affect democracy itself, such as stresses to social capital-the social cohesion, trust, norms, information flows and civic institutions that underpin healthy democracies ${ }^{14}-$ or increases in inequality and consequent concentrations of political power ${ }^{15}$. Other challenges we discuss-such as fiscal challengesare less specific to democratic systems.

Many developed democracies are already under stress ${ }^{16-18}$. Democratic institutions such as free press and fair elections have been under attack since the onset of the global financial $\mathrm{crisis}^{16}$. Trust in these institutions is declining in some developed democracies, especially among youth ${ }^{17,19}$. Several countries have recently elected populists who openly challenge some of these values, including Hungary, Italy, Poland, Turkey and the United States.

On the other hand, some have noted that key drivers of slowing economic growth in developed democracies reflect important gains in human well-being-for example, gains in women's' rights contributing to falling birth rates, and an abundance of durable goods fuelling shifts towards service economies ${ }^{20}$. However, even some proponents of intentionally slowing growth assert that many aspects of modern socioeconomic systems rely on long-run growth ${ }^{21,22}$.

${ }^{1}$ Cooperative Institute for Research in Environmental Sciences, University of Colorado Boulder, Boulder, CO, USA. ${ }^{2}$ Environmental Studies Program, University of Colorado Boulder, Boulder, CO, USA. ${ }^{3}$ Department of Economics, University of Colorado Boulder, Boulder, CO, USA. ${ }^{4}$ Bren School of Environmental Science and Management, University of California Santa Barbara, Santa Barbara, CA, USA. ${ }^{5}$ Department of Political Science, University of Colorado Boulder, Boulder, CO, USA. 凶e-mail: matthew.g.burgess@colorado.edu 

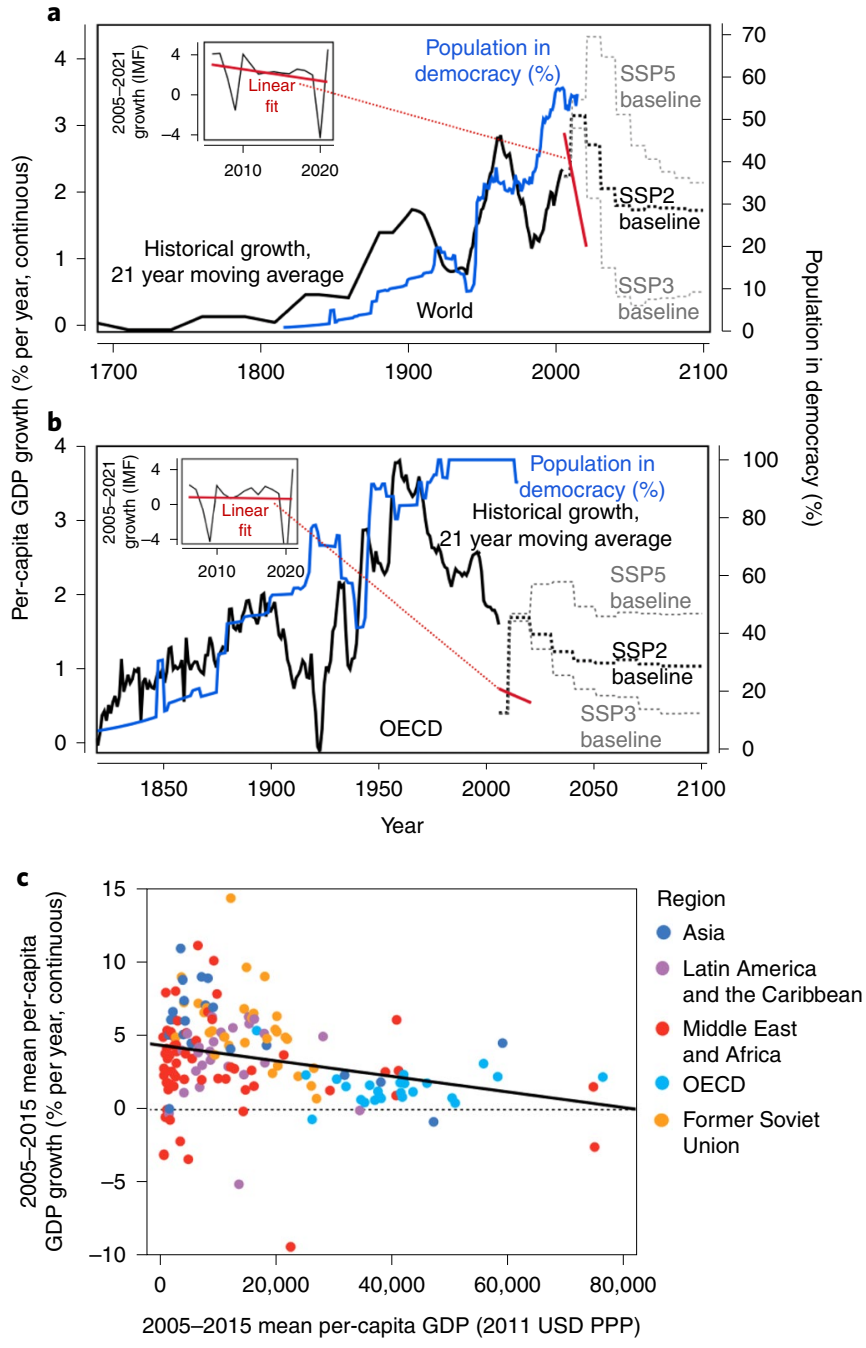

Fig. 1 | Historical growth and democracy trends. a,b, Historical trends (solid black; 21 year moving average) ${ }^{199}$, recent trends (inset and red line, based on the IMF April 2020 forecast $^{200}$ ) and SSP projections ('middle-of-the-road' SSP2, low-growth SSP3 and high-growth $\mathrm{SSP}^{38,39}$ ) of global per-capita GDP growth (in inflation-adjusted purchasing-power-parity (PPP) units), and historical trends in democracy ${ }^{3}$, focusing on global (a) and OECD (1990 members, following the SSPs ${ }^{38}$ ) (b) trends. c, The negative relationship between per-capita GDP and per-capita GDP growth (also in real PPP units) across countries in recent years

(2005-2015 averages) ${ }^{199}$ with an ordinary least squares (OLS) fit (black line) (omitting Qatar as an outlier) of $y=4.35-\left(5.34 \times 10^{-5}\right) x$ with $95 \%$ $\mathrm{Cl}$ of $-8.16 \times 10^{-5}$ to $-2.51 \times 10^{-5}$ for the gradient $(P=0.0003)$ and 3.70 to 5.00 for the intercept $(P<0.0001)$. Countries colour-coded according to SSP regional classifications ${ }^{38}$.

Certainly, modern socioeconomic systems have not existed under any other regime. Thus, it is reasonable to consider that modern socioeconomic systems could be stressed in a slow-growth or stagnant world.

We discuss strategies that developed democracies may adopt to overcome the fiscal and social challenges we identify. Our discussion is meant to be general, but we also focus some of our discussion specifically on the United States, Japan and Italy. The United States is the world's most economically and politically powerful democracy, and thus constructively anticipating its challenges may be especially important. Japan and Italy are two developed democracies that have already experienced two decades or more of relative economic stagnation (Fig. 2a, b). Since these three countries are also culturally and politically different from each other, they provide instructive contrasts in some of their experiences with challenges associated with slow growth, from which lessons can be drawn. We focus most of our discussion on domestic challenges, but slow growth could also have important geopolitical implications that deserve attention in future research.

To prepare developed democracies for the fiscal and social challenges of slow growth or stagnation, we call for a 'guided civic revival' that includes government and civic efforts aimed at decoupling social capital and individual well-being from economic growth, integrating diverse populations, improving opportunity for youth, improving the return on investment (ROI) in government spending and taxation and institutionally safeguarding core elements of democratic government. Limiting inequality and improving access to education are key to this agenda, as are government and grass-roots investments in social integration and building shared national identities, to combat headwinds of polarization. We discuss some specific policy suggestions previous studies have made pursuant to some of these objectives (which we do not necessarily endorse). However, our aim here is to catalyse discussion of these issues rather than to be any sort of 'final word'. There are many unanswered questions herein that should be a priority for multidisciplinary research before the consequences of slowing economic growth materialize more broadly.

\section{Why twenty-first-century growth could be slow}

Recently, some macroeconomists have argued that the twentieth century's rapid economic growth-much like the twentieth century's rapid population growth-may be a historical anomaly for structural reasons, ending soonest in developed countries. Population growth is slowing and populations are ageing ${ }^{23-25}$, thus reducing the relative size of workforces and increasing public debt from social welfare programmes for elderly citizens, as has happened recently in $\operatorname{Japan}^{26}$. Endogenous growth models-which emphasize innovation as a key driver of growth ${ }^{20,27}$ - suggest that population stagnation could stifle innovation ${ }^{28}$. Gains from physical capital accumulation are limited with a finite population. Gains in education and health-key determinants of human capital-seem to be slowing in developed countries ${ }^{22,29}$. Urbanization and female workforce participation cannot possibly exceed $100 \%$. Inventions of the nineteenth and twentieth centuries revolutionized nearly every sector of the economy simultaneously ${ }^{29}$. Some argue that this feat will unlikely be repeated, even by ongoing advances in high-technology sectors, which so far have not returned productivity growth to pre-1970 levels in either the United States or other developed democracies at the technological frontier ${ }^{29}$. Labour productivity growth may be more difficult to increase in service sectors, and richer countries have shifted towards more service-oriented economies ${ }^{20}$. In addition to these (possibly unstoppable) structural negative pressures on growth, many countries' growth may be hindered by high public and private debt burdens ${ }^{29,30}$ and inequality ${ }^{15}$.

Some economists argue that artificial intelligence and other transformative innovations on the horizon could maintain longer-term growth ${ }^{31}$-and perhaps even counteract the effects of ageing if labour shortages increase demand for productive automations $\mathrm{s}^{32}$-especially if human capital and complementary innovations catch up ${ }^{33}$. However, most leading macroeconomists in a recent survey ${ }^{9}$ projected slowing per-capita GDP growth across the world throughout the twenty-first century and disagreed only about the expected magnitude. Their median projection of average twenty-first-century US per-capita GDP growth was 1.5\% per year, compared with the $2 \%$ per year average from the twentieth century. Their median per-capita GDP growth projection for China was less than 3\% per year compared with more than $7 \%$ per year from 2000 to 2010 (ref. $^{2}$ ). Only in low-income countries did respondents 
a
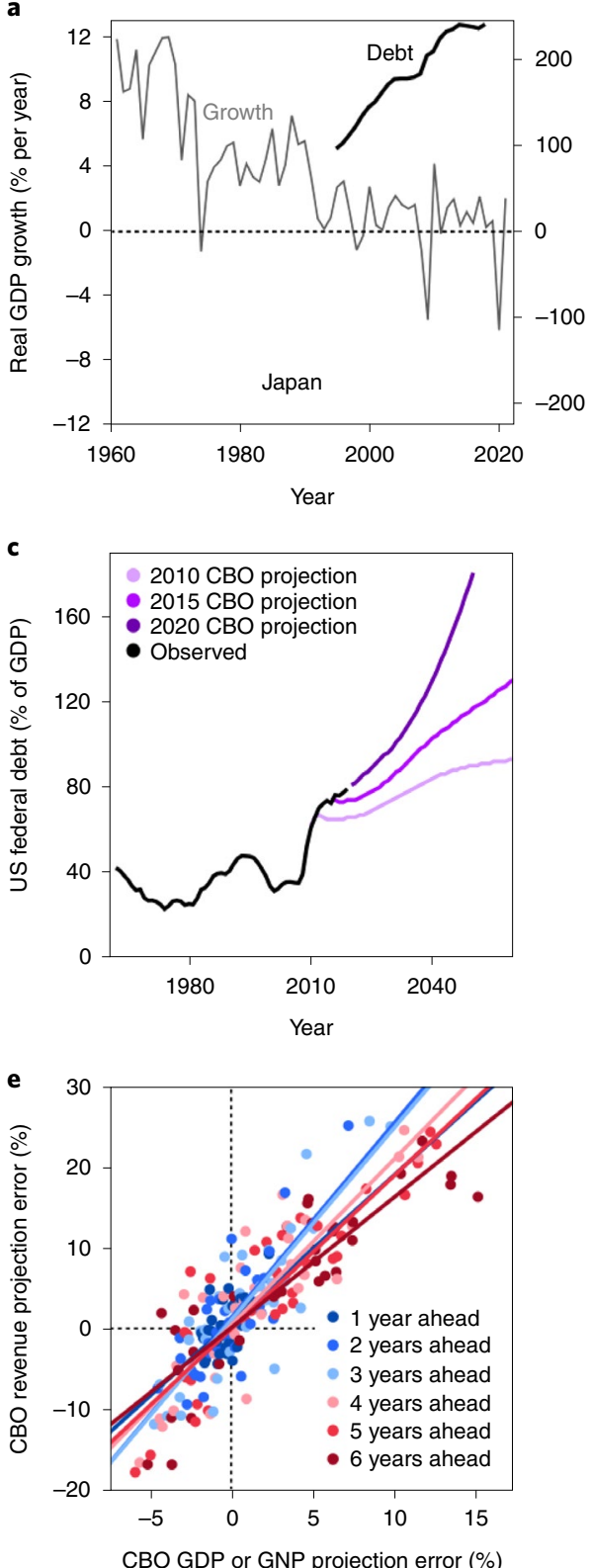

b
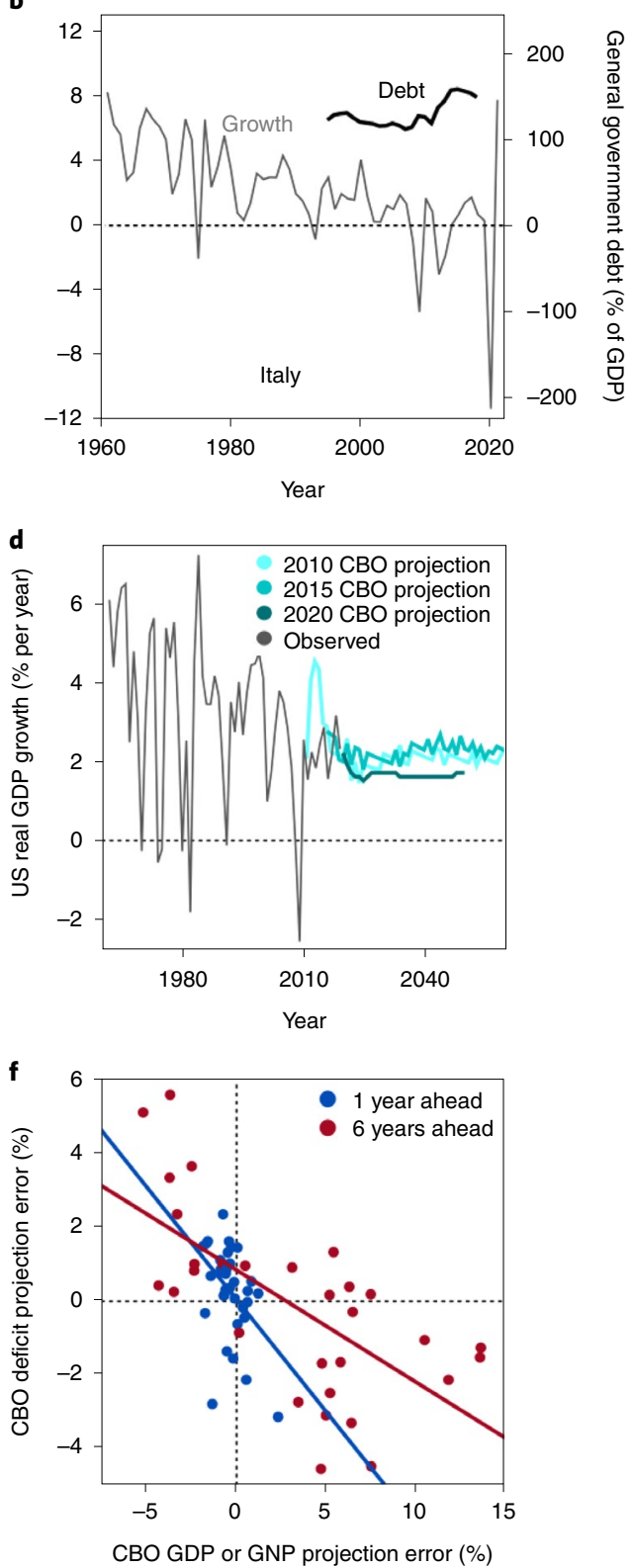

Fig. 2 | Slow growth and public debt. a,b, Real GDP growth and general government debt from recent decades in Japan (a) and Italy (b) ${ }^{69,201}$. Note that both Japan and Italy have had very little net population change since 2000 (ref. ${ }^{2}$ ), thus their growth rates in GDP and per-capita GDP over this period are broadly similar. c,d, Federal debt (c) and real GDP growth (d) observed and projected by the CBO202 in 2010, 2015 and January 2020 (all before COVID19). e,f, Correlations between CBO projection errors in nominal GDP or gross national product (GNP) and revenue (e) and fiscal deficit (f), over different projection horizons ${ }^{202,203}$. Lines indicate ordinary least squares (OLS) fits (see Supplementary Table 1 for coefficients, 95\% confidence intervals and $P$ values).

project twenty-first-century growth comparable to twentiethcentury growth ${ }^{9}$. Indeed, exogenous growth models predict declining growth with increasing affluence ${ }^{34}$, consistent with historical data $^{35-37}$ (Fig. 1c).

The Shared Socioeconomic Pathway (SSP) scenarios $^{38,39}$ used in climate change research, as well as other statistical and numerical economic projections ${ }^{40,41}$, also agree on widespread slowing of twenty-first-century economic growth (Fig. 1a,b). Moreover, authoritative economic forecasts-such as those by the International Monetary Fund (IMF) (which the SSPs are based on pre-2018 $8^{39}$ ) and national governments-have historically tended to over-project growth and were successively revised down ${ }^{42-46}$ (Fig. 1a,b). Failing to predict crises-as the ongoing COVID-19 crisis illustrates ${ }^{47}$-is only one among several reasons economic forecasts tend to be biased high. Other reasons that forecasts have tended to over-project economic growth include political pressures, changing productivity trends and output gaps failing to close as assumed (see refs. ${ }^{42-45,48}$ and references therein).

Population growth forecasts were also recently revised down ${ }^{25}$, with birth rates declining faster than anticipated in developing countries $^{49}$. Some demographers now anticipate substantial population declines in many regions of the world in the second half of the twenty-first century ${ }^{25,49}$. Damage caused by climate change, and efforts to mitigate climate change, may also slow future growth ${ }^{50-53}$. COVID-19 could slow long-term growth by discouraging trade or causing lasting human capital losses from education system 
disruptions ${ }^{47,54-56}$. Indeed, a retreat from globalization is a defining feature of the SSP scenario with slowest economic growth: 'Regional Rivalry' (SSP3) ${ }^{38,39}$ (Fig. 1a,b).

Separately from the debate about whether twenty-first-century growth will be slow, some environmental scientists and ecological economists argue that economic growth should be intentionally slowed, halted or even temporarily reversed (that is, de-growth) for the sake of sustainability (see, for example, refs. ${ }^{10,57-59}$ ). At the core of many of these arguments is pessimism about the feasibility of reducing the energy and material footprint of economic growth, combined with the fact that the current footprint appears unsustainable (see, for example, ref. ${ }^{60}$ ). Other ecological economists argue that high levels of productivity growth observed in developed countries during the mid-twentieth century may have been dependent on using energy sources (fossil fuels) with high energy return on investment (that is, little energy input is required for energy output), whereas renewables have lower energy return on investment ${ }^{22,61}$. Although we consider intentional de-growth unlikely in democracies, it is plausible that some countries could adopt policies that prioritize climate change mitigation or broader environmental protection over economic growth as climate change or other environmental challenges intensify in coming decades.

\section{Fiscal challenges}

Long-run slowdowns in economic growth could pose serious fiscal challenges to developed democracies.

A common measure of a country's debt burden is the ratio of government debt to GDP (but see a recent critique ${ }^{62}$ of this measure). When an economy is growing, its debt-to-GDP ratio can be reduced without running a fiscal surplus, but without any growth, a fiscal surplus is the only option. Indeed, during the past century, developed democracies have mostly run fiscal deficits and relied on growth to reduce their debt-to-GDP ratios $^{63}$. Consequently, long-run slowdowns in growth have coincided with recent debt levels greater than GDP in Japan and Italy (Fig. 2a, b), and the US Congressional Budget Office (CBO) projected a similar trend for US federal debt in the twenty-first century, even before the COVID-19 pandemic (Fig. 2c).

Slow growth also directly affects budget deficits by reducing tax revenues and increasing demands on spending, via social safety-net programmes and (depending on the acuteness and severity of the slowdown) fiscal stimulus. In the United States, for instance, the CBO's forecasts of growth have gradually declined over the past decade, whereas their forecasts of public deficits and debt burdens have coincidently increased (Fig. 2c,d). We can also see the direct effect of growth on deficits in the strong correlations between the CBO's forecast errors of growth and both revenues (Fig. 2e) and deficits (Fig. 2f). This correlation deserves attention from fiscal planners, given the tendency of growth forecasts to over-project ${ }^{42-45}$. Other coincident twenty-first-century forces-such as the need to mitigate or adapt to climate change-will place additional, but worthwhile, demands on public spending, increasing deficits and debt burdens, all else being equal.

Logically, there is an upper limit beyond which the debt-to-GDP ratio is unsustainable, thus countries facing complete stagnation (that is, zero growth) must eventually balance their budgets. However, at what point this upper limit occurs, and to what extent countries with very slow but still positive growth must avoid deficits, is a topic of active debate in economics. There is some empirical evidence that debt levels higher than $90 \%$ of GDP have historically been associated with slower growth via 'debt overhang ${ }^{30,64}$, that is, where over-leveraged countries are prevented from issuing debt to finance productive investment opportunities. The other direct impact of high debt is high interest payments, which can consume a high fraction of government budgets and eventually reduce investor confidence in a government's ability to repay the debt, resulting in higher interest rates and debt payments ${ }^{65}$. This can create a debt spiral requiring a bailout from international institutions or a write-down from creditors, as occurred, for instance, in Greece following the Great Recession ${ }^{66}$.

On the other hand, the current COVID-19 crisis clearly creates a strong case for running sizeable deficits in the short run. As Blanchard and Leigh ${ }^{67}$ showed, countries that adopted fiscal austerity policies after the Great Recession under-performed economically relative to their forecasts, whereas countries that adopted expansionary fiscal policies over-performed.

Moreover, some macroeconomists have recently argued that there is fiscal space for larger deficits in slow-growing developed democracies, even in the medium to longer term, due to low interest rates on government debt and relatively high fiscal multipli$\mathrm{ers}^{62,68}$. Declining interest rates on government debt can prevent interest payments as a percentage of GDP from rising, even if the debt-to-GDP ratio rises. Blanchard ${ }^{68}$ showed that the burden of a dollar borrowed by the government today shrinks over time as long as the nominal growth rate (GDP growth plus inflation) exceeds the interest rate on government debt-an inequality he showed has almost always held in the post-World War II United States. Furman and Summers ${ }^{62}$ argued that low interest rates can also be a sign that increasing government spending would crowd out relatively little private investment (because the interest rates that investors are willing to accept on government bonds are affected by how lucrative private investment opportunities are), which would suggest a higher fiscal multiplier, all else being equal.

Japan's and Italy's recent experiences with public debt amidst persistent slow growth illustrate both the link between growth and debt-to-GDP ratios, and the ambiguities (highlighted above) in what this means for desirable deficits in the future. Real GDP growth has been persistently low ( $<1 \%$ on average) in Japan since the mid-1990s and in Italy since the early 2000s (Fig. 2a,b). General government debt-to-GDP ratios rose in both countries during this period, exceeding $100 \%$ in both countries and $200 \%$ in Japan (Fig. 2a,b), making these two of the most indebted countries in the developed world ${ }^{69}$. However, interest rates on government debt have also declined, to the point where both countries actually now pay a smaller fraction of their GDP in interest than they did in the mid-1990s, when their debt-to-GDP ratios were lower ${ }^{62}$ (Fig. 3a). Moreover, in contrast to the inflation crises in the late 1970s and early 1980s, inflation has declined and remained low (Fig. 3b). As Furman and Summers ${ }^{62}$ argue, low interest rates, relatively low interest payments (historically speaking) and low inflation all suggest that there may currently be fiscal space for somewhat higher deficits in the short term (certainly in the context of the COVID-19 recovery). However, the prospect of persistent declines in growth throughout the twenty-first century (Fig. 1) suggests that the issue of sustainable public deficits and debts deserves continued attention. As we argue below, maximizing the return on investment in public spending and taxation is a no-regrets policy, irrespective of what one thinks sustainable debt limits are.

Finally, we note that, although the 'classical dichotomy' theory in macroeconomics ${ }^{70}$ suggests that monetary policy is neutral in the long run (that is, does not affect real growth; in contrast to the short run), some economists dispute this, arguing that expansionary monetary policy might be useful in addressing challenges of long-run stagnation. For instance, some economists argue that price stickiness can make monetary policy non-neutral ${ }^{71}$. Modern Monetary Theory, which is influential in some political circles despite being on the fringes of mainstream economic thought, argues that central governments that control their own currencies are limited only by inflation in their abilities to expand the money supply ${ }^{72}$ (but see also criticisms of Modern Monetary Theory, for example, ref. ${ }^{73}$ ). We do not intend to adjudicate this debate here, except to note that excessive reliance on printing money to address fiscal problems has 
a

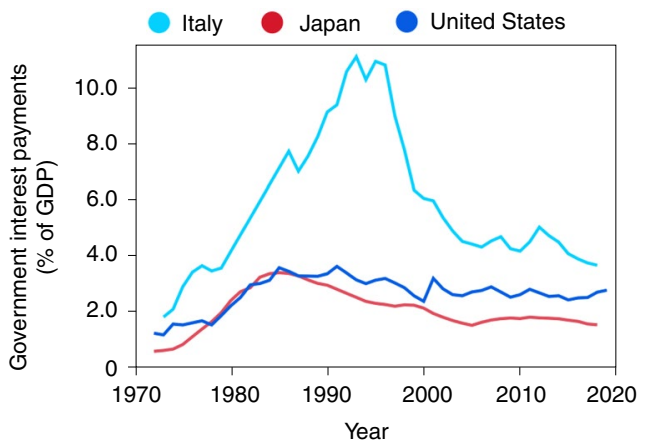

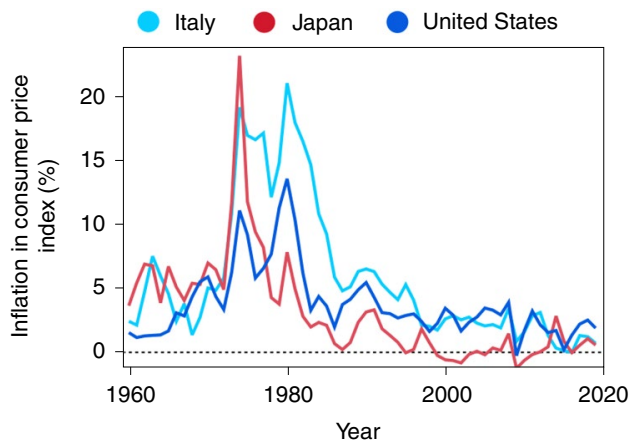

Fig. 3 | Government interest burdens and inflation. a,b, Trends in government interest payments expressed as a percentage of GDP (a) and inflation in the consumer price index (b), in Italy, Japan and the United States (data from ref. ${ }^{2}$ ).

sometimes resulted in economic disaster-for instance in Weimar Germany in the $1920 \mathrm{~s}^{74}$ and more recently in Venezuela ${ }^{75}$.

\section{Social challenges}

Slow economic growth makes it harder to lift all boats simultaneously. A completely stagnant economy (in terms of per-capita GDP) is zero-sum, at least in dollar terms: for every winner there is a loser. Thus, slower growth makes it more challenging for governments to craft policies with broadly felt economic benefits, and intuitively makes society more competitive, with resulting potential for personal stress, conflict, poverty and inequality, and gaps between expectations and reality, all of which have potential to strain the social fabric. Below and in Fig. 4, we highlight several social challenges that could accompany slow growth in developed democracies.

Opportunity and inequality. All else being equal, slowing economic growth decreases the rate of job creation, and can increase pressure on both government revenues and social safety nets, which can cause governments to cut spending in opportunity-generating areas such as education ${ }^{76}$. If slowing growth causes retirement savings to grow more slowly than expected, that can incentivize older workers to delay retirement ${ }^{77,78}$. Each of these forces has the potential to result in increased unemployment, especially for youth ${ }^{79}$, and as a result also increase the competitiveness of education systems, as the ratio of elite positions to prospective candidates declines-what Turchin $^{80}$ calls 'elite overproduction'.

Indeed, the experiences of Italy, Japan, the United States, and the rest of the Organisation for Economic Co-operation and Development (OECD) bear this out, though with instructive variation (Fig. 4a). As OECD economic growth rates gradually declined during the second half of the twentieth century (Fig. 1b), unemployment gradually increased, especially for youth (ages 15-24 years) (Fig. 4a). In Italy, youth unemployment has been especially pronounced, varying around 30\% since the early 1980s, and spiking since the Great Recession (Fig. 4a). By contrast, Japan's youth unemployment was only $4 \%$ in 2019 , and the United States' was $8 \%$ (Fig. 4a). Japan's labour force participation rate is also higher than Italy's (62\% versus $49 \%$, and $47 \%$ versus $26 \%$ for youth in 2020 $\left(\right.$ ref. $\left.^{2}\right)$ ), meaning that the difference in unemployment rates understates the difference in employment.

Differences between Italy's and Japan's recent experiences are due to several factors. One is population ageing, which is pronounced in both countries, but slightly more so in Japan ${ }^{2}$. This results in a shortage of workers in Japan especially, which drives down unemployment, all else being equal. Japan also has strong cultural norms, both against companies laying off workers, even during economic downturns (for example, ref. ${ }^{81}$ ), and promoting work and long working hours as a key currency of social status ${ }^{82}$. Conversely, Italy's culture more strongly values work-life balance and encourages unmarried youth to live with their parents ${ }^{83}$, which-combined with relatively generous unemployment benefits, wage stagnation and a competitive labour market-may provide lower incentives to work ${ }^{84}$. Heterogeneity in labour market protections-with newer, younger workers disproportionately having flexible contracts that are easier to terminate during downturns in Southern Europe (in contrast to other OECD regions)- has also contributed to Italy's unemployment being especially pronounced among youth, compared with older workers ${ }^{85}$. Similarly, a more sequential education system-where workers are expected to learn key competencies on the job-may put youth at a greater disadvantage in Italy, especially in the face of downturns and precarious employment ${ }^{85,86}$.

Decreasing opportunity for youth via slow growth has the potential to entrench inequality in at least two ways. First, decreasing opportunity may create fear of downward mobility among richer families that catalyses support for policies that entrench class privileges ${ }^{87,88}$. (Firms may analogously support polices that erode competition or labour rights; such erosion has occurred in the United States since its mid-twentieth-century growth peak ${ }^{89,90}$.) Second, if slow growth puts downward pressure on public education funding, richer youth are more likely to have access to private alternatives.

There can also be a more fundamental link between slowing growth and increasing economic inequality, as highlighted by Piketty ${ }^{91}$. Specifically, Piketty ${ }^{91}$ (see also Krusell and Smith ${ }^{92}$ ) showed that capital's share of income (a measure related to inequality, since capital is mostly owned by the rich) should approach $r s / g$, where $r$ is the rate of return on capital, $s$ is the net savings rate (increase in the capital stock divided by income net of depreciation ${ }^{92}$ ) and $g$ is the economic growth rate. If growth $(g)$ goes to zero but both $r$ and $s$ stay positive, then inequality clearly explodes.

In practice, $s$ is likely to decline as $g$ declines, making rising inequality not inevitable ${ }^{22,92,93}$. For instance, while per-capita GDP growth has followed an inverted V-shaped pattern (rising, then falling) over the past century in developed countries-peaking in the mid-1960s (Fig. 1b) -inequality has only followed the opposite V-shaped pattern (falling, then rising to its previous peak) in English-speaking developed countries, instead following more of an L-shaped pattern in non-English-speaking developed countries ${ }^{94}$ (as shown in Fig. 4b for the United States, Italy and Japan).

A key proximate cause of this difference seems to be higher taxes and safety net spending, especially in most western Mainland European and Scandinavian countries versus English-speaking countries (Fig. 5). Greater cultural solidarity within non-English-speaking developed countries may be a related 
Italy

a
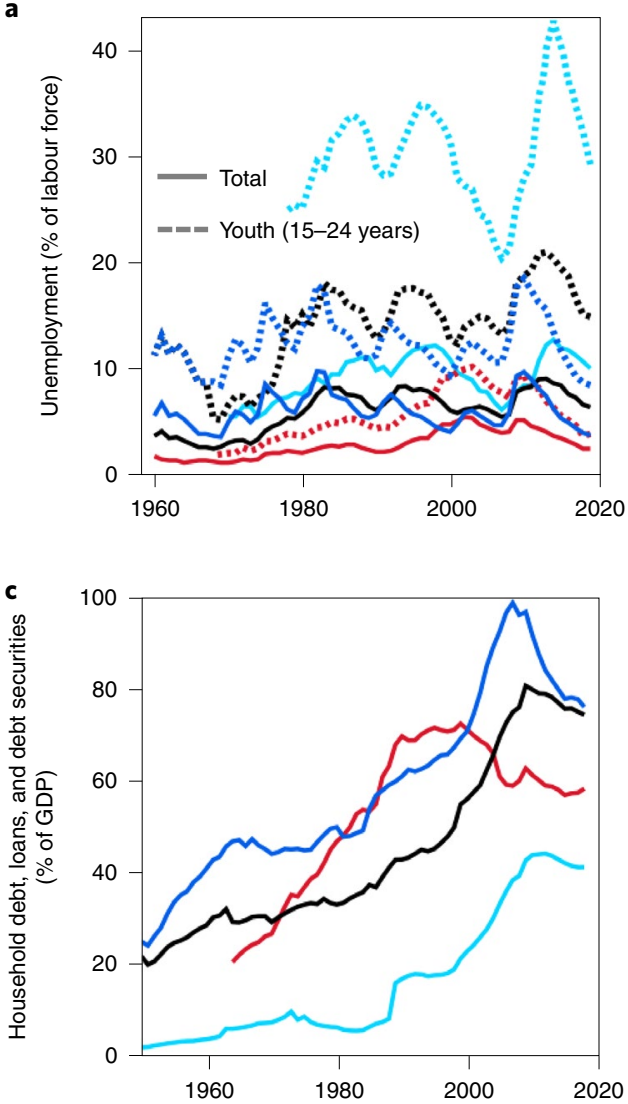

e

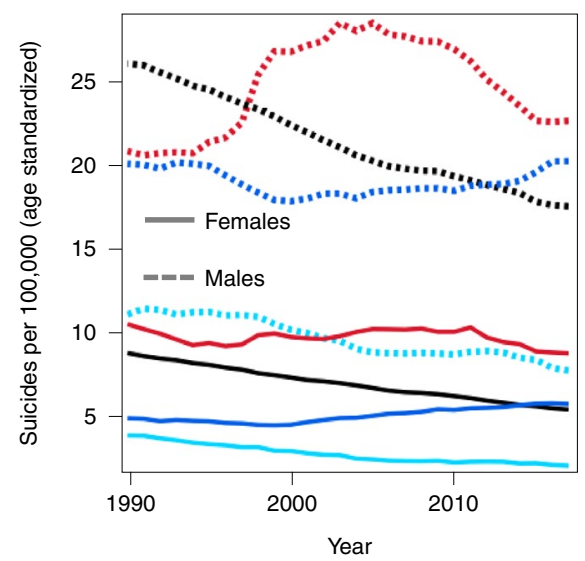

United States

OECD average

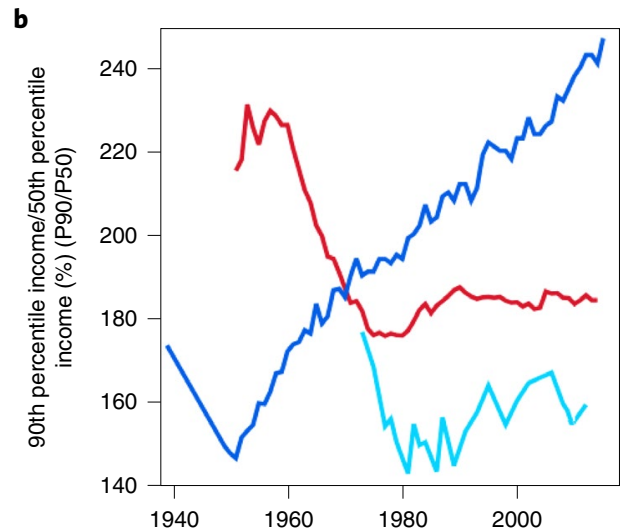

d

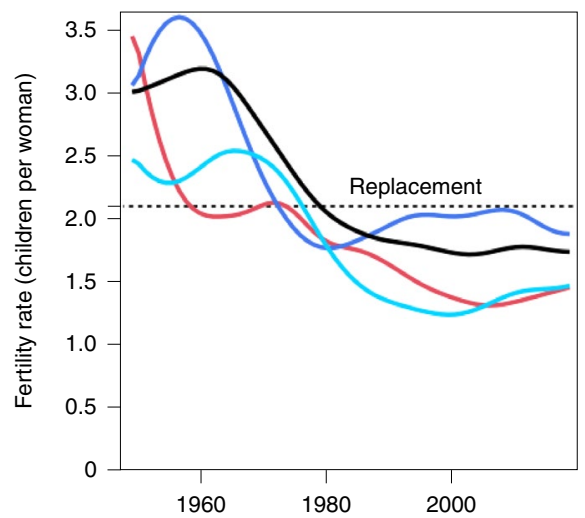

f

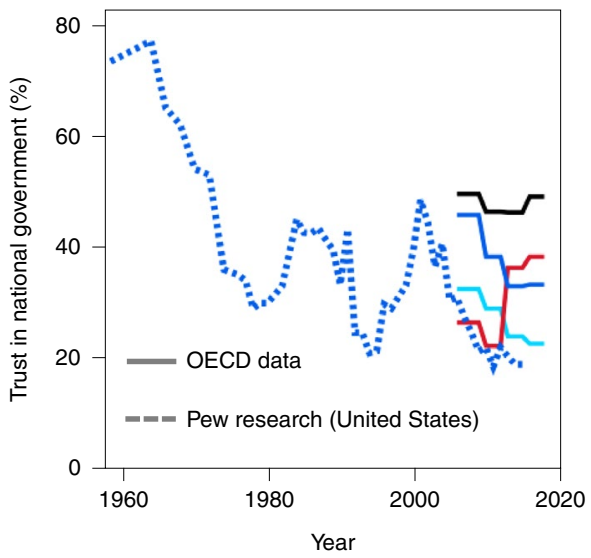

Fig. 4 | Social challenges that slow growth could exacerbate. a-f, Comparison of six different social trends in Italy, Japan, the United States and the OECD average when available (1990 membership, as in Fig. 1): unemployment rates (data from ref. ${ }^{2}$ ) (a), income inequality measured as the ratio between the 90th and 50th percentile incomes (data from ref. ${ }^{204}$ ) (b), household debt (data from ref. ${ }^{205}$ ) (c), birth rates (data from ref. ${ }^{206}$ ) (replacement rate of 2.1 also shown for reference) (d), suicide rates (data from ref. ${ }^{207}$ ) (e) and trust in government (data from refs. ${ }^{139,208,209}$ ) (f).

ultimate cause. Some research suggests that cultural solidarity between poor and rich is a key determinant of political support for economic redistribution among the rich $^{95,96}$, as well as broader public goods provisioning and social capital ${ }^{97-100}$. In the United States, some scholars have traced declining support for universal social safety net programmes after the 1964 Civil Rights Act to racism (see, for example, ref. ${ }^{101}$ ). Regardless of the cause, rising inequality increases socioeconomic segregation, concentrates political power, strains public trust and increases potential for conflict, all of which undermine democracy ${ }^{15}$, as we expand on below.
Personal finance. As economic growth has slowed over the past $50-60$ years in developed democracies (Fig. 1b), household debt has steadily increased (Fig. 4c). Of course, other factors besides growth may be more important in explaining rising household debt. Two such factors are: (i) financial development increasing access to credit $^{102}$ and (ii) wage stagnation relative to economic growth and costs of education (a key human capital input) and housing ${ }^{103}$. Household debt can create overhang ${ }^{104}$, preventing individuals from making productive capital (including human capital) investments, and it also can make aggregate demand and financial systems more 

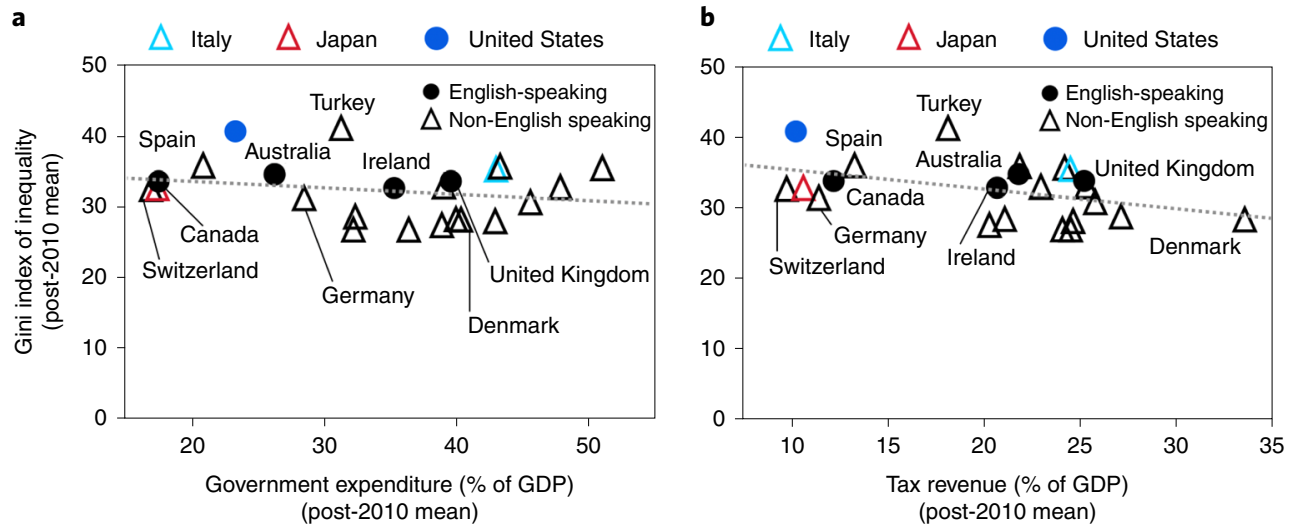

Fig. $\mathbf{5}$ | Size of government and inequality. a,b, Comparison across OECD countries (1990 members) of the Gini index of economic inequality versus government expenditures (\% of GDP) (a) and central government tax revenues (\% of GDP), excluding fines, penalties and most social security contributions (data from ref. ${ }^{2}$ ) (b), with bivariate ordinary least squares (OLS) fits (dashed grey lines) of $y=35.4-0.091 x$ with $95 \% \mathrm{Cl}$ of -0.27 to 0.084 $(P=0.29)$ on the slope and 29.1 to $41.7(P<0.0001)$ on the intercept $(\mathbf{a})$, and $y=37.9-0.27 x$ with $95 \% \mathrm{Cl}$ of -0.53 to $-0.017(P=0.038)$ on the slope and 32.4 to $43.4(P<0.0001)$ on the intercept $(\mathbf{b})$.

sensitive to shocks ${ }^{102}$. These challenges could be exacerbated in the short to medium run if growth continues to slow faster than consumers and lenders expect, though consumer and lender behaviour would adjust in the long run.

Looking ahead, it is worth considering some potentially profound implications of long-run stagnation for several aspects of personal finance that consumers and households in many developed democracies often take for granted. As discussed above, as economic growth approaches zero, so too must the growth in the capital stock to prevent runaway inequality ${ }^{92,93}$. Zero growth in the capital stock would mean that, on average, new investments are just barely large enough to cover depreciation. More plainly, exponential growth on modest investments would no longer be an attainable path to wealth accumulation for the average household. Thus, individual contribution models for retirement and education saving (common in the United States)-where savings primarily accrue through interest on manageable, regular contributions-might need to be reconsidered in favour of more collective saving models (for example, where taxes on workers subsidize retirement for all and progressive taxation subsidizes education for low-income citizens). Similarly, in a stagnant economy, with declining populations ${ }^{25}$, building wealth through housing appreciation could also cease to be common. Indeed, many Japanese housing markets have experienced declining prices during the country's stagnation period ${ }^{105}$. If these pillars of personal financial planning needed to be reconsidered, probably so too would related aspects of the social safety net. For instance, social planning for retirement and education funding might no longer be able to depend on the average citizen having adequate private savings.

Mental health, families and gender. Long-run economic stagnation could affect mental and material well-being (especially of youth), potentially exacerbating several challenging trends which are already apparent across developed democracies. Many of these trends follow directly from the effect of stagnation on youth employment and opportunity, discussed above, while others are contemporaneous with potentially synergistic effects.

At the individual level, economic anxieties can be damaging to individuals' mental health ${ }^{106}$. These effects may be especially severe among young people, who, in many developed countries, are the first generation in centuries with lower average wealth than their parents ${ }^{107}$. However, this also affects older people, especially those being left behind by automation and de-industrialization ${ }^{108}$. This mismatch between expectations and reality under slowing growth may be especially challenging psychologically and socially. Indeed, economic opportunities failing to meet expectations-especially among elite and bourgeois youth-is thought to have been a key catalyst for some political revolutions (see, for example, refs. ${ }^{80,109}$ ). In the near future at least, any negative impact of slowing growth on youth mental health will coincide with already skyrocketing incidences of youth anxiety and depression ${ }^{110}$. All of these trendscombined with longer-running trends towards urbanization and female workforce participation ${ }^{49}$ - have caused marriage and birth rates to decline, such that they are below replacement (2.1 births per woman) in every OECD country in North America, Europe, Oceania and East Asia ${ }^{111}$ (Fig. 4d).

Members of all genders may experience unique social challenges in stagnant economies. For instance, in Japan, slow growth over the past three decades has coincided with a marked increase in suicides and social withdrawal among men ${ }^{112,113}$ (Fig. 4e). A smaller male-dominated suicide increase was observed in the United States following the Great Recession ${ }^{114}$ (Fig. 4e). Interestingly, however, suicide rates have been much lower in Italy-without an analogous spike in the male rate coincident with the onset of economic stagnation (Fig. 4e). Future research should explore possible sociocultural and climatic/environmental causes of this difference. Social integration is known to reduce suicide risk ${ }^{115,116}$, including in Italy ${ }^{117,118}$, and there is some evidence for weather-related effects on suicide risk ${ }^{119}$. In the United States, recent declines in male-dominated manufacturing sectors have led to declines in marriage rates ${ }^{120}$ and increases in male rates of suicide and drug abuse ${ }^{108}$. Many studies have found links between violent crime and economic and social alienation among young men (see, for example, ref. ${ }^{121}$ ). Neighbourhood-level density of single-parent households (likely to be exacerbated by declining economic opportunity for young $\operatorname{men}^{120}$ ) also correlates with violent crime rates among young men ${ }^{122}$.

Declines in economic growth might also pose unique challenges to women in developed democracies (as well as in other societies, of course, which lies beyond the scope of this paper). At the macro level, there are strong positive correlations between GDP per capita and various measures of women's advancement and equality relative to men ${ }^{123}$. Although economic downturns often disproportionately affect men's employment ${ }^{79,124,125}$ (COVID-19 being an exception ${ }^{126}$ ), downturns can also affect safety net spending (for example, health care, childcare and paid leave subsidies) that affect women disproportionately (for example, as occurred in Sweden 
in the early $1990 \mathrm{~s}^{127}$ ). Recessions have also been associated with increased occupational gender segregation ${ }^{128}$ and higher marriage rates in regions with job losses concentrated in female-dominated sectors $^{120}$. Single-parent households (which are mostly headed by women) are especially vulnerable to economic downturns ${ }^{129}$, and recessions affecting male-dominated sectors are associated with lower marriage rates and more out-of-wedlock births ${ }^{120}$. Lastly, economic downturns can create status and identity threats to men that result in rises in nostalgia for patriarchal social structures (see, for example, ref. ${ }^{130}$ ). Of course, challenges associated with short-term recessions do not necessarily foreshadow challenges in long-run slowdowns, but these are nonetheless gender-related concerns that societies trending towards slower growth should prepare for.

Trust and conflict. Slowing economic growth has the potential to stress societies' social fabrics in several ways, with ethnoculturally diverse societies perhaps being especially vulnerable. Across many societies (not only developed democracies), studies have found slowing growth and negative economic shocks to be associated with declining social trust (see, for example, refs. ${ }^{131,132}$, although Searing ${ }^{133}$ found a positive effect of recessions on trust in Latin America), declining support for political incumbents ${ }^{7}$ and democratic institutions ${ }^{134}$, and increased likelihood of conflict (see, for example, refs. ${ }^{135,136}$; see Blattman and Miguel $^{137}$ for a review). Some of these associations have bidirectional causality (that is, these factors affect growth as well as being affected by growth) (see, for example, ref. ${ }^{138}$ ).

In the United States, Pew research polls ${ }^{139}$ found that nearly $80 \%$ of the public trusted the federal government in the mid-1960s but that that number has declined to below $20 \%$ in recent years (Fig. 4f). Similar data are not available as far back for other OECD countries, to our knowledge, but trust in government in Japan and Italy have been steadily below $50 \%$ since 2006, with Italy's declining (Fig. 4f).

Rising inequality-especially pronounced in English-speaking countries (among developed democracies) - exacerbates each of these challenges. For instance, it leads to geographic and social segregation by income, concentrates political power among the wealthy and reduces social trust (separately from slow growth or recessions) $)^{15,94,140,141}$. Piketty ${ }^{142}$ notes that major political parties in several developed democracies have recently re-aligned to more ubiquitously represent the cultural and economic interests of the elite ('Brahmin left vs merchant right ${ }^{\text {'142 }}$ ). Gilens and Page ${ }^{143}$ argue that the extent to which post-1980s US government policy empirically matches preferences of the wealthy seems more functionally oligarchic than democratic.

Sociopolitical stresses from inequality can be exacerbated by ethnocultural divisions, which intersect with economic inequality via racial and ethnic inequalities. Ethnocultural divisions-especially ethnic polarization, whereby members of society divide themselves into small numbers of roughly equally sized groups-are associated with lower levels of social trust and civic participation ${ }^{100}$, support for redistribution ${ }^{96}$ and public goods provisioning ${ }^{97}$, and higher levels of conflict ${ }^{144}$. In her book Political Tribes ${ }^{145}$, Chua notes that inequality and ethnocultural divisions can combine to create situations where there is a 'market-dominant minority'-a numerical ethnocultural minority with disproportionate economic and political power. In such situations, both the minority and majority groups feel threatened and entitled to be dominant, in ways that catalyse tribalism and have often caused democracies to fail.

Picking up on several of the trends described in this section, Putnam and Romney Garrett ${ }^{90}$ describe coincident 100 -year trends-rising from the 1930s to the 1960s, and subsequently declining-of several measures of social and civic health in the United States. These measures include economic equality, bipartisanship, various measures of social connection and civic participation and measures of political and social collectivism (as opposed to individualism). We note that these trends coincide with the rise and fall of per-capita GDP growth ${ }^{29}$ (Fig. 1b), though the strength of the causality in each direction is not entirely clear.

\section{Guided civic revival}

How can developed democracies prepare themselves for these fiscal and social challenges of a possible slow-growth century? There are many unanswered questions herein that should be an urgent priority for multidisciplinary research. Indeed, recent monographs have addressed some aspects of the challenges described above (15,20,57,90. $^{\text {. }}$

Building on this and other research, we argue for a 'guided civic revival', aimed at decoupling social capital (social trust, civic participation, collectivism and so on) and individual well-being from economic growth, reducing inequality, integrating diverse populations, improving opportunity for youth, increasing the return on investment (ROI) in government spending and taxation and institutionally safeguarding core institutional elements of democracy so that they can withstand stress. We use the term 'civic revival' to denote the importance of grass-roots, bottom-up civic forces to the success of such a project. We use the term 'guided' to denote the fact that governments will need to play a role as well. We outline specific objectives of what we call 'guided civic revival' below, and we discuss ideas aimed at achieving each objective discussed in relevant literature (though we do not necessarily endorse every idea mentioned).

Strengthen democratic institutions. Given that some of the potential stresses on democracy are already apparent ${ }^{17}$, and it is unlikely that any society will be able to avoid all of them, democracies should solidify key democratic institutions-free and fair elections, balance of powers, rule of law, minimized influence of money in politics-as deeply and unchangeably as possible (for example, constitutionally in constitutional democracies, or in laws) so that they can withstand short-term stresses from demagogic leaders or social movements. The recent history of democratic institutions in the United States, in contrast to Turkey and Hungary, provides an illustrative example. All three countries elected populist leaders with open disrespect of each country's democratic norms. Yet, the United States' constitutionally enshrined separations of powers and transfer of power norms have held, even as the outgoing president refused to concede the 2020 election past the point when the results were certified, culminating in the Capitol riots.

In the long term, however, we acknowledge that there are probably limits to how long institutions can withstand declines in social capital and public trust in government, not to mention ballooning debts. Thus, in the face of long-run economic stagnation, developed democracies will need to mitigate the fiscal and social stresses described above in order to avoid repeated stress tests on their democratic norms and institutions.

Increase social integration and reduce economic inequality. If social capital is to be decoupled from economic growth, then we argue that building strong shared identities within democratic societies is critical. This may be especially important-and potentially challenging-in ethnoculturally diverse societies. Reducing economic inequality is key to this project.

In every known society, people form group identities-leading to trust, favouritism and altruism towards in-group members, and distrust and sometimes hostility towards out-groups ${ }^{145-148}$. Group identities can centre on biological constructs, such as families, clans or ethnic groups, or they can centre on social constructs such as national patriotism or religion. These tendencies underpin the challenges to widespread social cooperation observed in heterogeneous societies ${ }^{95-99}$.

One of the most effective ways to build shared identities and social trust in diverse societies is through social integrationwhereby members of a society have frequent social contact and 
cultural exchanges ${ }^{148-150}$. For instance, while Putnam ${ }^{100}$ found ethnocultural diversity to be negatively associated with social trust and civic engagement in US neighbourhoods, a similar study in Canada $^{151}$ found the same pattern among older people, but the opposite pattern among younger people-who had more often grown up together and fostered a shared multicultural identity. Integrating neighbourhoods and education systems allows children from diverse economic and ethnocultural backgrounds to grow up together, and sometimes reduces ethnocultural tensions ${ }^{152-154}$. However, the conditions under which integration or contact occur are important to these outcomes ${ }^{155}$.

Underfunded education systems and rising economic inequality have become major barriers to school and neighbourhood integration in many modern democracies, including the United States ${ }^{15}$. Therefore, investments in (and lowering costs of) public education-which also reduce economic inequality, have fiscal benefits from high ROI and disproportionately benefit youth ${ }^{15}$ - could be a cornerstone of democratic resilience in a slow-growth future. Adapting education systems to provide more directly job-relevant training might improve opportunity for youth, especially during economic downturns ${ }^{85,86}$. Populations continuing to age could also create opportunity for youth (and possibly cause labour shortages) ${ }^{156}$.

Combatting economic inequality would benefit from other institutions as well-both redistributive and 'pre-distributive' (that is preventing rent-seeking by the powerful for their benefit $\left.{ }^{15}\right)$. In large cities, increasing affordable housing supplies and restricting foreign speculation could lessen economic segregation ${ }^{157}$. Some studies have found that universal social welfare programmes (for example, universal health care and education) boost social trust more than means-tested programmes ${ }^{158}$, but universal programmes may also be costlier. Universal redistributive institutions such as 'baby bonds' - whereby governments provide all newborns with an illiquid sum of money that grows until the baby becomes an adult and can then access it-have been proposed (see, for example, ref. $\left.{ }^{159}\right)$, to address racial and class-based wealth gaps in the United States, and could also enhance education access and youth opportunity. Similarly, housing vouchers that subsidize economically disadvantaged families to move to neighbourhoods of their choosing (rather than in geographically concentrated subsidized housing) has improved economic mobility in experiments ${ }^{160}$, and could also promote integration. Many sociologists and some economists argue that restoring and safeguarding the rights of organized labour may also be important ${ }^{22,161}$, though we note-in light of countervailing concerns about offshoring - that the high-water mark of US labour rights in the early post-WWII period also coincided with historical lows in trade and immigration ${ }^{162}$.

Beyond education and inequality reduction, guided civic revival needs efforts to counter recent trends of polarization and segmentation. Some have recommended that citizens engage in local politics, to build community from the bottom up ${ }^{90,163}$. Others have argued for more drastic measures, such as mandatory (or socially expected) civil service for youth to boost integration and civic engagement (see, for example, ref. ${ }^{164}$ ). Others still have argued for carefully matching immigration rates to the pace of-and efforts towardsintegration ${ }^{165}$. However, immigration-especially high-skilled immigration-is also a source of economic growth ${ }^{166,167}$, and for many developed countries a key strategy to combat the challenges of an ageing population ${ }^{49}$.

Declines in organized religion and the rise in social media use are two other factors that probably will need to be addressed in building shared identities and growth-independent social capital. Social media poses a unique twenty-first-century challenge to social cohesion through its fragmentation, moralization and emotionalization of media and news consumption ${ }^{168}$. Religion has been a key catalyst for social capital in the United States and other societies in the past ${ }^{90,169}$, and also seems to fulfil key belonging needs. Indeed, Henrich and colleagues ${ }^{170,171}$ argue that emphases on non-kin-based group identity-originating in Christian churchesled to prosperity-enhancing psychologies and values in Western European countries and Western offshoots.

As religious participation declines, there is a danger that people will fill their belonging needs through associations with quasi-religious fundamentalist groups, fuelled by social media. Some argue that this is already occurring in the United States, for instance, with the rise of movements such as QAnon on the political right ${ }^{172}$, and what has been described as the 'Successor Ideology' and 'The Elect' on the political left ${ }^{173,174}$. An alternative would be to construct new 'civil religions ${ }^{175}$ - with group identities encompassing all members within a country (thus being more inclusive in multicultural societies, such as the United States, than previous national identities have been ${ }^{90}$ ). One way to accomplish this in diverse, pluralistic societies may be what Chua ${ }^{145}$ refers to as a 'super-group' identity (and that others call a 'dual identity'176,177), whereby members of a society can retain individual sub-group identities (for example, 'Canadian-American'), but also strongly identify with the shared national identity (for example, 'American'). The objective of the super-group identity concept is to facilitate a shared identity across cultural groups without encouraging the pro-assimilation politics and prejudice towards cultural minorities that other types of nationalism can catalyse ${ }^{145,177}$.

In summary, post-growth societies will need to build and maintain social capital by reducing inequality and increasing cultural solidarity. Among developed democracies, this seems an especially pressing concern in English-speaking countries (for example, the United States, the United Kingdom and Canada), which are more diverse and unequal than most of their non-English-speaking counterparts. Given that cultural solidarity between rich and poor increases support for economic redistribution ${ }^{96}$, there could be a virtuous cycle between reducing inequality and other strategies aimed at integration and building shared identities.

Increase return on public investment. The fiscal challenge of a slow-growth future is to strike a balance between using public spending to reduce inequality and enhance opportunity for youthon top of other sizable expenses such as infrastructure repair and climate-change mitigation ${ }^{52}$-while maintaining sustainable debt burdens (as discussed in the Fiscal challenges section). There is still ongoing debate regarding the extent to which or how soon slow growth would require reducing deficits or balancing public budgets. Interest rates may remain smaller than growth rates so long as growth is positive (even if very small ${ }^{62,68}$, and both high private debt burdens and underfunded public goods (for example, infrastructure and education) may increase fiscal multipliers (that is, the economic benefits of public spending $)^{104}$. Of course, what constitutes an accurate benchmark for growth-and by extension, what constitutes an under-performing economy in need of stimulus-is closely related to the debates regarding sustainable and feasible growth pathways ${ }^{22}$, summarized above.

However, despite this uncertainty, increasing ROI and reducing waste in government spending and taxation seems like a no-regrets policy that is beneficial irrespective of interest rates (and, indeed, growth futures). Education, research and development (R\&D) and infrastructure, which provide public goods and positive externalities, are areas with historically high long-run ROI in government spending ${ }^{178}$. Closing costly tax loopholes and reducing corruption are other key areas. In the United States, reform to the economically inefficient health-care system ${ }^{179}$ may also be a fiscal imperative.

Even with improvements in spending ROI and reducing tax avoidance, some countries may eventually need to raise taxes, if slow growth and other factors such as climate change, increasing societal complexity ('Wagner's law'180,181), and global integration $^{182}$ increase spending needs, and if slow growth eventually also 
increases the need for budget balance. In the United States, some scholars and many Democratic politicians have called for higher taxes on top incomes and wealth both to finance spending needs and to reduce inequality (see, for example, ref. ${ }^{183}$ ). Indeed, the size of the state (especially tax revenue), relative to GDP, is negatively correlated with economic inequality, and the United States is one of the most unequal countries in the OECD (Fig. 5). Funding of spending increases by progressive tax increases has the additional advantage that the spending could have higher multipliers than the taxation (some of which would target money that would have otherwise been saved $)^{62}$.

However, while tax increases on top incomes may indeed be called for, we note that US federal revenue as a percentage of GDP has been nearly constant in the post-WWII period, despite large variations in top income tax rates-a phenomenon known as Hauser's law $^{184}$. A common feature of OECD countries with significantly higher tax revenue (compared with GDP) than the United States is a sizeable national consumption tax or value-added tax (VAT). For instance, Denmark (bottom-right point in Fig. 5b) has a $25 \% \mathrm{VAT}^{185}$. The advantage of a VAT (or consumption tax) is that consumption is a tax base which is both very large and difficult to offshore. A large base means that the same revenue can be raised at lower tax rates (and thus smaller market distortions) than from taxes with smaller tax bases ${ }^{186}$. Property taxes-especially on residential housing, as opposed to commercial real estate-may be similarly resistant to offshoring consequences (although they have a smaller base), and also contribute to reductions in wealth inequality, especially if revenues are collected and distributed evenly over economically diverse regions (for example, states, instead of counties).

Decouple subjective well-being from growth. As others have noted (see, for example, refs. ${ }^{22,187,188}$ ), societies will need to find ways to decouple improving well-being from additional growth in a post-growth future. Some evidence suggests this could be challenging. For instance, self-reported life satisfaction strongly correlates with economic affluence and income, within and across coun$\operatorname{tries}^{189,190}$. Moreover, migration patterns disproportionately flow from poorer to richer countries, and such migrations increase life satisfaction ${ }^{191,192}$. Citizens of OECD countries are used to younger generations being economically better-off than older generationsa trend which may already be halting ${ }^{107}$ and is incompatible with stagnation. This creates potential for a gap between expectations and reality as growth slows.

On the other hand, there is some evidence: (i) that income's effect on well-being satiates (for example, at US\$60,000-90,000 per year, as estimated recently by Jebb et al. ${ }^{193}$ ), (ii) that it depends on the relative incomes of peers ${ }^{194}$ and (iii) that some measures of well-being are less correlated with income than others (for example, daily emotions less than life satisfaction ${ }^{195}$ ). Undoubtedly, many factors affect subjective well-being in addition to affluence and income, as evidenced by the fact that subjective well-being has recently declined in the United States and in some other countries even as they became richer ${ }^{194}$. Benjamin et al. ${ }^{13}$ found that security, family, personal freedoms, health, meaning, purpose and moral satisfaction similarly or more strongly determine subjective well-being compared with income. The importance of these factors is evident, for example, the documented role of religion in social capital formation ${ }^{169}$, and may be related to Italy's relatively low suicide rates (Fig. 4e). These patterns reinforce the importance of maintaining democratic institutions and personal freedoms in a slow-growth world, as well as the importance of building shared identities and cross-cultural solidarity. These patterns may also suggest that the field of positive psychology has an important role to play in a slow-growth future (see Kaufman ${ }^{196}$ for a recent review).

Other, more direct, economic interventions that have been proposed to safeguard well-being (both subjective and economic) in the face of slow growth include universal basic income ${ }^{187}$ (which would need to be financed by tax increases, for example, as noted by Yang ${ }^{197}$ ) and work sharing (where individual positions are shared between multiple workers working fewer hours ${ }^{188}$. Work sharing could prove challenging in some professions where continuity of accountability for tasks is important, but may be feasible in other professions. Universal basic income might disincentivize work if the level is too high, but there is relatively little evidence for this effect at modest levels that do not go far beyond basic needs ${ }^{197}$. Of course, some gains in well-being may come naturally as growth slows (as Vollrath ${ }^{20}$ outlines). Policy interventions should focus on specific challenges.

Whatever the specific pathways that societies pursue to safeguard well-being in the face of slowing growth or stagnation, it seems clear that these pathways will need to include both grassroots and cultural forces-for example, in families and local efforts to build social capital $^{163}$ - and government actions, via the safety net, maintaining personal and political freedoms and perhaps also nudges toward increased civic participation and social solidarity.

\section{Conclusions}

We started from the observation that modern developed democracies have arisen during a period of unprecedented global economic growth, which may be coming to an end, either unavoidably ${ }^{20,29,198}$ or-as some argue ${ }^{10,57}$-deliberately by necessity. Although the future of economic growth is uncertain ${ }^{9}$, the possibility of long-run stagnation arriving this century in developed countries has become too significant to ignore.

We reviewed evidence suggesting that developed democracies may face a variety of fiscal social challenges under long-run stagnation, including high debt burdens; declining economic opportunity, family formation, and mental health among youth; rising inequality; challenges to personal finance; declines in social trust; and increases in conflict. Some of these challenges are already empirically apparent (Figs. 2 and 4; see also ref. ${ }^{90}$ ), and they intersect with other major societal disruptions (besides growth slowdowns) such as automation, globalization and climate change.

To address these challenges, we argued for a mixture of government and grassroots actions-a 'guided civic revival'-aimed at strengthening key democratic institutions and freedoms, increasing return on investment (ROI) in public spending and taxation, increasing economic opportunity for youth, reducing inequality and increasing social solidarity (perhaps especially in multicultural democracies). In countries, such as the United States, with relatively small government and high inequality, we argued that the size of government-and consequently taxes-may need to increase. Although we take slow growth as a premise for our analysis, most of our prescriptions may be 'no-regrets' solutions that are beneficial whether or not growth slows.

Our primary objective in this paper is to bring attention to these important issues, in order to stimulate public discussion and multidisciplinary scholarly research, as many unanswered questions remain. For instance, if slow long-run growth is inevitable, how long (if at all) should governments try to delay it using economic policies? How much public and private debt can stagnant economies afford? When should countries pursue fiscal stimulus in slow- or zero-long-run-growth worlds? How does slow growth or stagnation affect the optimal size of government? How should families, firms and societies fund education, health care and retirement, and build or maintain wealth, amidst long-run stagnation? How can stagnant economies reduce inequality, and how much inequality should such societies accept? How can ethnoculturally diverse societies best promote shared identities and social solidarity, while also reducing nationalistic prejudice against minorities? How can political polarization be reduced, and how can key social, political and fact-finding institutions be protected against its effects? What 
social, environmental or other advantages or opportunities might slow growth create? Similar to guided civic revival, research agendas answering these and other related questions would probably benefit society even if growth does not slow as significantly or as quickly as many predict.

Received: 6 April 2021; Accepted: 29 September 2021;

Published online: 18 November 2021

\section{References}

1. Galor, O. \& Weil, D. N. Population, technology, and growth: from Malthusian stagnation to the demographic transition and beyond. Am. Econ. Rev. 90, 806-828 (2000).

2. World development indicators. World Bank https://databank.worldbank. org/source/world-development-indicators (2020).

3. Roser, M. Democracy. Our World in Data https://ourworldindata.org/ democracy (2013).

4. Barro, R. J. Democracy and growth. J. Econ. Growth 1, 1-27 (1996).

5. Acemoglu, D. \& Robinson, J.A. Why Nations Fail: The Origins of Power, Prosperity, and Poverty (Currency, 2012).

6. Acemoglu, D., Naidu, S., Restrepo, P. \& Robinson, J. A. Democracy does cause growth. J. Polit. Econ. 127, 47-100 (2019).

7. Feng, Y. Democracy, political stability and economic growth. Br. J. Polit. Sci. 27, 391-418 (1997)

8. Barro, R. J. Determinants of democracy. J. Polit. Econ. 107, S158-S183 (1999).

9. Christensen, P., Gillingham, K. \& Nordhaus, W. Uncertainty in forecasts of long-run economic growth. Proc. Natl Acad. Sci. USA 115 5409-5414 (2018).

10. Kallis, G., Paulson, S., D'Alisa, G. \& Demaria, F. The Case for Degrowth (Wiley, 2020).

11. Van den Bergh, J. C. J. M. Environment versus growth-a criticism of 'degrowth' and a plea for 'a-growth'. Ecol. Econ. 70, 881-890 (2011).

12. 2021 best global universities rankings. US News https://www.usnews.com/ education/best-global-universities/rankings (2020).

13. Benjamin, D. J., Heffetz, O., Kimball, M. S. \& Szembrot, N. Beyond happiness and satisfaction: toward well-being indices based on stated preference. Am. Econ. Rev. 104, 2698-2735 (2014).

14. Putnam, R.D. Democracies in Flux: The Evolution of Social Capital in Contemporary Society (Oxford Univ. Press, 2004).

15. Stiglitz, J.E. The Price of Inequality: How Today's Divided Society Endangers Our Future (WW Norton, 2012).

16. Schenkkan, N. \& Repucci, S. The freedom house survey for 2018 : democracy in retreat. J. Democr. 30, 100-114 (2019).

17. Mounk, Y. The People vs. Democracy: Why Our Freedom is in Danger and How to Save It (Harvard Univ. Press, 2018).

18. Hyde, S. D. Democracy's backsliding in the international environment. Science 369, 1192-1196 (2020).

19. Hetherington, M.J. Why Trust Matters: Declining Political Trust and the Demise of American Liberalism (Princeton Univ. Press, 2005).

20. Vollrath, D. Fully Grown (Univ. of Chicago Press, 2020).

21. Gilding, P. The Great Disruption: Why the Climate Crisis Will Bring on the End of Shopping and the Birth of a New World (Bloomsbury, 2011).

22. Jackson, T. The post-growth challenge: secular stagnation, inequality and the limits to growth. Ecol. Econ. 156, 236-246 (2019).

23. Max Roser, H.R. \& Ortiz-Ospina, E. World population growth. Our World in Data https://ourworldindata.org/world-population-growth (2019).

24. World population prospects 2019. United Nations Population Division https://population.un.org/wpp/ (2019).

25. Vollset, S. E. et al. Fertility, mortality, migration, and population scenarios for 195 countries and territories from 2017 to 2100: a forecasting analysis for the global burden of disease study. Lancet 396, 17-23 (2020).

26. Muto, I., Oda, T. \& Sudo, N. Macroeconomic impact of population aging in Japan: a perspective from an overlapping generations model. IMF Econ. Rev. 64, 408-442 (2016).

27. Romer, P. M. The origins of endogenous growth. J. Econ. Perspect. 8 3-22 (1994).

28. Jones, C.I. The End of Economic Growth? Unintended Consequences of a Declining Population, Technical Report (National Bureau of Economic Research, 2020).

29. Gordon, R.J. The Rise and Fall of American Growth: The US Standard of Living since the Civil War (Princeton Univ. Press, 2016).

30. Reinhart, C. M., Reinhart, V. R. \& Rogoff, K. S. Public debt overhangs: advanced-economy episodes since 1800. J. Econ. Perspect. 26, 69-86 (2012).

31. Brynjolfsson, E. \& McAfee, A. Race against the Machine: How the Digital Revolution Is Accelerating Innovation, Driving Productivity, and Irreversibly Transforming Employment and the Economy (Digital Frontier, 2011).
32. Acemoglu, D. \& Restrepo, P. Secular stagnation? The effect of aging on economic growth in the age of automation. Am. Econ. Rev. 107, 174-179 (2017).

33. Brynjolfsson, E., Rock, D. \& Syverson, C. The productivity J-curve: how intangibles complement general purpose technologies. Am. Econ. J. Macroecon. 13, 333-372 (2021).

34. Solow, R. M. A contribution to the theory of economic growth. Q. J. Econ. 70, 65-94 (1956).

35. Mankiw, N. G., Romer, D. \& Weil, D. N. A contribution to the empirics of economic growth. Q. J. Econ. 107, 407-437 (1992).

36. Baumol, W. J. Productivity growth, convergence, and welfare: what the long-run data show. Am. Econ. Rev. 76, 1072-1085 (1986).

37. Tilman, D., Balzer, C., Hill, J. \& Befort, B. L. Global food demand and the sustainable intensification of agriculture. Proc. Natl Acad. Sci. USA 108, 20260-20264 (2011)

38. Riahi, K. et al. The shared socioeconomic pathways and their energy, land use, and greenhouse gas emissions implications: an overview. Glob. Environ. Chang 42, 153-168 (2017).

39. Dellink, R., Chateau, J., Lanzi, E. \& Magné, B. Long-term economic growth projections in the shared socioeconomic pathways. Glob. Environ. Chang 42, 200-214 (2017).

40. Müller, U.K., Stock, J.H. \& Watson, M.W. An Econometric Model of International Long-Run Growth Dynamics, Technical Report (National Bureau of Economic Research, 2019).

41. Startz, R. The next hundred years of growth and convergence. J. Appl. Econ. 35, 99-113 (2020).

42. De Resende, C. An Assessment of IMF Medium-Term Forecasts of GDP Growth, IEO Background Paper No. BP/14/01 (IMF, 2014).

43. Frankel, J. Over-optimism in forecasts by official budget agencies and its implications. Oxf. Rev. Econ. Policy 27, 536-562 (2011).

44. Frankel, J. \& Schreger, J. Over-optimistic official forecasts and fiscal rules in the Eurozone. Rev. World Econ. 149, 247-272 (2013).

45. Burgess, M.G., Langendorf, R.E., Ippolito, T. \& Pielke Jr, R. Optimistically biased economic growth forecasts and negatively skewed annual variation. Preprint at https://osf.io/preprints/socarxiv/ vndqr (2020).

46. Burgess, M. G., Ritchie, J., Shapland, J. \& Pielke, R. Jr IPCC baseline scenarios have over-projected $\mathrm{CO}_{2}$ emissions and economic growth. Environ. Res. Lett. 16, 014016 (2021).

47. Baldwin, R. \& di Mauro, B.W. Economics in the Time of COVID-19. A VoxEU.org Book (Centre for Economic Policy Research, 2020).

48. Timmermann, A. An evaluation of the world economic outlook forecasts. IMF Staff. Pap. 54, 1-33 (2007).

49. Bricker, D. \& Ibbitson, J. Empty Planet: The Shock of Global Population Decline (Hachette, 2019).

50. Burke, M., Hsiang, S. M. \& Miguel, E. Global non-linear effect of temperature on economic production. Nature 527, 235-239 (2015).

51. Woodard, D. L., Davis, S. J. \& Randerson, J. T. Economic carbon cycle feedbacks may offset additional warming from natural feedbacks. Proc. Nat Acad. Sci. USA 116, 759-764 (2019)

52. Brown, P. T., Moreno-Cruz, J. \& Caldeira, K. Break-even year: a concept for understanding intergenerational trade-offs in climate change mitigation policy. Environ. Res. Commun. 2, 095002 (2020).

53. Kolstad, C. D. \& Moore, F. C. Estimating the economic impacts of climate change using weather observations. Rev. Environ. Econ. Policy 14, 1-24 (2020).

54. Burgess, S. \& Sievertsen, H.H. Schools, skills, and learning: the impact of COVID-19 on education. Vox ${ }^{E U}$ https://voxeu.org/article/impact-covid-19education (2020).

55. Maliszewska, M., Mattoo, A. \& Van Der Mensbrugghe, D. The potential impact of COVID-19 on GDP and trade: a preliminary assessment. World Bank https://openknowledge.worldbank.org/handle/10986/33605 (2020).

56. Ranald, P. COVID-19 pandemic slows global trade and exposes flaws in neoliberal trade policy. J. Aust. Polit. Econ. 85, 108-114 (2020).

57. Jackson, T. Prosperity without Growth: Foundations for the Economy of Tomorrow (Taylor \& Francis, 2016)

58. Kallis, G. In defence of degrowth. Ecol. Econ. 70, 873-880 (2011)

59. Raworth, K. Doughnut Economics: Seven Ways to Think Like a 21st-Century Economist (Chelsea Green, 2017).

60. Kallis, G. Radical dematerialization and degrowth. Philos. Trans. R. Soc. A 375, 20160383 (2017)

61. Ayres, R.U. \& Warr, B. The Economic Growth Engine: How Energy and Work Drive Material Prosperity (Edward Elgar, 2010).

62. Furman, J. \& Summers, L.A. Reconsideration of fiscal policy in the era of low interest rates. Brookings https://www.brookings.edu/wp-content/ uploads/2020/11/furman-summers-fiscal-reconsideration-discussion-draft. pdf (2020).

63. General government deficit (indicator). OECD https://data.oecd.org/gga/ general-government-deficit.htm (2020). 
64. Krugman, P. Financing vs. forgiving a debt overhang. J. Dev. Econ. 29, 253-268 (1988).

65. Cole, H. L. \& Kehoe, T. J. Self-fulfilling debt crises. Rev. Econ. Stud. 67, 91-116 (2000).

66. De Santis, R.A. The Euro area sovereign debt crisis: safe haven, credit rating agencies and the spread of the fever from Greece, Ireland and Portugal, ECB working paper. European Central Bank https://www.ecb.europa.eu/ pub/pdf/scpwps/ecbwp1419.pdf (2012).

67. Blanchard, O. J. \& Leigh, D. Growth forecast errors and fiscal multipliers. Am. Econ. Rev. 103, 117-120 (2013).

68. Blanchard, O. Public debt and low interest rates. Am. Econ. Rev. 109, 1197-1229 (2019).

69. General government debt (indicator). OECD https://data.oecd.org/gga/ general-government-debt.htm\#indicator-chart (2020).

70. Patinkin, D. Money, Interest, and Prices: An Integration of Monetary and Value Theory (Harper \& Row, 1965).

71. Ball, L. \& Romer, D. Real rigidities and the non-neutrality of money. Rev. Econ. Stud. 57, 183-203 (1990).

72. Tymoigne, E. \& Wray, L. R. Modern money theory 101: a reply to critics, working paper series. Levy Institute https://www.levyinstitute.org/pubs/ wp_778.pdf (2013).

73. Mankiw, N. G. A skeptic's guide to Modern Monetary Theory. AEA Pap. Proc. 110, 141-144 (2020).

74. Webb, S.B. Hyperinflation and Stabilization in Weimar Germany (Oxford Univ. Press, 1989).

75. Pittaluga, G. B., Seghezza, E. \& Morelli, P. The political economy of hyperinflation in Venezuela. Public Choice 186, 337-350 (2021).

76. Fabricant, M. \& Brier, S. Austerity Blues: Fighting for the Soul of Public Higher Education (JHU Press, 2016).

77. Li, D., Richards, M. R. \& Wing, C. Economic downturns and nurse attachment to federal employment. Heal. Econ. 28, 808-814 (2019).

78. Amuedo-Dorantes, C. \& Borra, C. Retirement decisions in recessionary times: evidence from Spain. BE J. Econ. Anal. Policy 17, 20160201 (2017).

79. Hoynes, H., Miller, D. L. \& Schaller, J. Who suffers during recessions? J. Econ. Perspect. 26, 27-48 (2012).

80. Turchin, P. \& Nefedov, S.A. Secular Cycles (Princeton Univ. Press, 2009).

81. Shin, D. \& Alam, M. S. Lean management strategy and innovation: moderation effects of collective voluntary turnover and layoffs. Total Qual. Manag. Bus. Excell.-https://doi.org/10.1080/14783363.2020.1826923 (2020).

82. Ono, H. Why do the Japanese work long hours? Sociololgical perspectives on long working hours Japan. Jpn. Labor Issues 2, 35-49 (2018).

83. Manacorda, M. \& Moretti, E. Why do most Italian youths live with their parents? Intergenerational transfers and household structure. J. Eur. Econ. Assoc. 4, 800-829 (2006).

84. Ponzellini, A. M. Work-life balance and industrial relations in Italy. Eur. Soc. 8, 273-294 (2006)

85. Pastore, F. Why is youth unemployment so high and different across countries? IZA World Labor https://wol.iza.org/articles/why-is-youthunemployment-so-high-and-different-across-countries/long (2018).

86. Marelli, E. \& Vakulenko, E. Youth unemployment in Italy and Russia: aggregate trends and individual determinants. Econ. Labour Relat. Rev. 27, 387-405 (2016).

87. Lyken-Segosebe, D. \& Hinz, S. E. The politics of parental involvement: how opportunity hoarding and prying shape educational opportunity. Peabody J. Educ. 90, 93-112 (2015).

88. Reeves, R.V. Dream Hoarders: How the American Upper Middle Class Is Leaving Everyone Else in the Dust, Why That Is a Problem, and What to Do about It (Brookings Institution Press, 2018).

89. Gutiérrez, G. \& Philippon, T. Declining competition and investment in the US, technical report. National Bureau of Economic Research https://www. nber.org/papers/w23583 (2017).

90. Putnam, R. D. \& Romney Garrett, S. The Upswing: How America Came Together a Century Ago and How We Can Do It Again (Simon \& Schuster, 2020).

91. Piketty, T. Capital in the Twenty-First Century (Harvard Univ. Press, 2014).

92. Krusell, P. \& Smith, A. A. Jr Is Piketty's 'second law of capitalism' fundamental? J. Polit. Econ. 123, 725-748 (2015).

93. Jackson, T. \& Victor, P. Confronting inequality in the new normal: basic income, factor substitution and the future of work, technical report, CUSP working paper. Centre for the Understanding of Sustainable Prosperity https://cusp.ac.uk/themes/s2/wp11/ (2018).

94. Roser, M. \& Ortiz-Ospina, E. Income inequality. Our World in Dato https://ourworldindata.org/income-inequality (2013).

95. Brady, D. \& Finnigan, R. Does immigration undermine public support for social policy? Am. Sociol. Rev. 79, 17-42 (2014).

96. Rueda, D. Food comes first, then morals: redistribution preferences, parochial altruism, and immigration in Western Europe. J. Polit. 80 , 225-239 (2018).
97. Alesina, A., Baqir, R. \& Easterly, W. Public goods and ethnic divisions. Q. J. Econ. 114, 1243-1284 (1999).

98. Alesina, A., Devleeschauwer, A., Easterly, W., Kurlat, S. \& Wacziarg, R. Fractionalization. J. Econ. Growth 8, 155-194 (2003).

99. Alesina, A. \& Ferrara, E. L. Ethnic diversity and economic performance. J. Econ. Lit. 43, 762-800 (2005).

100. Putnam, R. D. E pluribus unum: diversity and community in the twenty-first century: the 2006 Johan Skytte Prize lecture. Scand. Polit. Stud. 30, 137-174 (2007).

101. McGhee, H. The Sum of Us: What Racism Costs Everyone and How We Can Prosper Together (One World, 2021).

102. Debelle, G. Macroeconomic implications of rising household debt. Preprint at https://papers.ssrn.com/sol3/papers.cfm?abstract_id=786385 (2007)

103. Barba, A. \& Pivetti, M. Rising household debt: its causes and macroeconomic implications-a long-period analysis. Camb. J. Econ. 33, 113-137 (2009).

104. Bernardini, M. \& Peersman, G. Private debt overhang and the government spending multiplier: evidence for the United States. J. Appl. Econ. 33, 485-508 (2018).

105. Hirayama, Y. \& Izuhara, M. Housing in Post-growth Society: Japan on the Edge of Social Transition (Routledge, 2018).

106. Ananat, E. O., Gassman-Pines, A., Francis, D. V. \& Gibson-Davis, C. M. Linking job loss, inequality, mental health, and education. Science 356, 1127-1128 (2017)

107. Kurz, C.J., Li, G. \& Vine, D.J. in Handbook of US Consumer Economics (Haughwout, A., \& Mandel, B. eds.) 193-232 (Academic, 2019).

108. Case, A. \& Deaton, A. Rising morbidity and mortality in midlife among white non-Hispanic Americans in the 21st century. Proc. Natl Acad. Sci. USA 112, 15078-15083 (2015).

109. Davies, J. C. Toward a theory of revolution. Am. Sociol. Rev. 27, 5-19 (1962).

110. Twenge, J.M. IGen: Why Today's Super-connected Kids Are Growing up Less Rebellious, More Tolerant, Less Happy-and Completely Unprepared for Adulthood-and What That Means for the Rest of Us (Simon and Schuster, 2017).

111. Fertility rates (indicator). OECD https://data.oecd.org/pop/fertilityrates.htm (2020).

112. Koo, J. \& Cox, W. M. An economic interpretation of suicide cycles in Japan. Contemp. Econ. Policy 26, 162-174 (2008).

113. Suwa, M. \& Suzuki, K. The phenomenon of 'hikikomori' (social withdrawal) and the socio-cultural situation in Japan today. J. Psychopathol. 19, 191-198 (2013).

114. Harper, S., Charters, T. J., Strumpf, E. C., Galea, S. \& Nandi, A. Economic downturns and suicide mortality in the USA, 1980-2010: observational study. Int. J. Epidemiol. 44, 956-966 (2015).

115. Durkheim, E. Suicide: A Study in Sociology (Routledge, 1952).

116. Berkman, L. F., Glass, T., Brissette, I. \& Seeman, T. E. From social integration to health: Durkheim in the new millennium. Soc. Sci. Med. 51, 843-857 (2000).

117. Pfeti, A. \& Miotto, P. Social and economic influence on suicide: a study of the situation in Italy. Arch. Suicide Res. 5, 141-156 (1999).

118. Detotto, C. et al. The role of family in suicide rate in Italy. Econ. Bull. 31, 1509-1519 (2011).

119. Deisenhammer, E. Weather and suicide: the present state of knowledge on the association of meteorological factors with suicidal behaviour. Acta Psychiatr. Scand. 108, 402-409 (2003).

120. Autor, D., Dorn, D. \& Hanson, G. When work disappears: manufacturing decline and the falling marriage market value of young men. Am. Econ. Rev. Insights 1, 161-178 (2019).

121. Blau, J. R. \& Blau, P. M. The cost of inequality: metropolitan structure and violent crime. Am. Sociol. Rev. 47, 114-129 (1982).

122. AEI-Brookings Working Group on Poverty and Opportunity. Opportunity, responsibility, and security: a consensus plan for reducing poverty and restoring the American dream. Brookings https://www.brookings.edu/ research/opportunity-responsibility-and-security-a-consensus-plan-forreducing-poverty-and-restoring-the-american-dream/ (2015).

123. Stoet, G. \& Geary, D. C. A simplified approach to measuring national gender inequality. PloS ONE 14, e0205349 (2019).

124. Wall, H.J. The 'man-cession' of 2008-2009: It's big, but it's not great. The Reg. Econ. https://www.stlouisfed.org/publications/regional-economist/ october-2009/the-mancession-of-20082009-its-big-but-its-not-great (2009).

125. Hobijn, B., Sahin, A. \& Song, J. The unemployment gender gap during the 2007 recession. Curr. Issues Econ. Financ. 16, 1-7 (2010).

126. Alon, T. M., Doepke, M., Olmstead-Rumsey, J. \& Tertilt, M. The impact of COVID-19 on gender equality, technical report. National Bureau of Economic Research https://www.nber.org/papers/w26947 (2020) 
127. Evertsson, M. \& Duvander, A.-Z. Parental leave-possibility or trap? Does family leave length effect Swedish women's labour market opportunities? Eur. Sociol. Rev. 27, 435-450 (2011).

128. Bansak, C., Graham, M. E. \& Zebedee, A. A. Business cycles and gender diversification: an analysis of establishment-level gender dissimilarity. Am. Econ. Rev. 102, 561-565 (2012).

129. Castrillo, C., Martín, M. P., Arnal, M. \& Serrano, A. in Poverty, Crisis and Resilience (eds Boost, M. et al.) 143-160 (Edward Elgar, 2020).

130. Mutz, D. C. Status threat, not economic hardship, explains the 2016 presidential vote. Proc. Natl Acad. Sci. USA 115, E4330-E4339 (2018).

131. Mikucka, M., Sarracino, F. \& Dubrow, J. K. When does economic growth improve life satisfaction? Multilevel analysis of the roles of social trust and income inequality in 46 countries, 1981-2012. World Dev. 93, 447-459 (2017).

132. Chaves, C., Castellanos, T., Abrams, M. \& Vazquez, C. The impact of economic recessions on depression and individual and social well-being: the case of Spain (2006-2013). Soc. Psychiatry Psychiatr. Epidemiol. 53, 977-986 (2018).

133. Searing, E. A. Love thy neighbor? Recessions and interpersonal trust in Latin America. J. Econ. Behav. Organ. 94, 68-79 (2013).

134. Gurr, T. R. On the political consequences of scarcity and economic decline. Int. Stud. Q. 29, 51-75 (1985).

135. Miguel, E., Satyanath, S. \& Sergenti, E. Economic shocks and civil conflict: an instrumental variables approach. J. Polit. Econ. 112, 725-753 (2004).

136. Miguel, E. \& Satyanath, S. Re-examining economic shocks and civil conflict. Am. Econ. J. Appl. Econ. 3, 228-232 (2011).

137. Blattman, C. \& Miguel, E. Civil war. J. Econ. Lit. 48, 3-57 (2010).

138. Bjørnskov, C. in The Oxford Handbook of Social and Political Trust (ed. Uslaner, E.M.) Ch. 22 (Oxford Univ. Press, 2018).

139. Public trust in government: 1958-2021. Pew Research https://www. pewresearch.org/politics/2021/05/17/public-trust-in-government-19582021/ (2021).

140. Kawachi, I., Kennedy, B. P., Lochner, K. \& Prothrow-Stith, D. Social capital, income inequality, and mortality. Am. J. Public Health 87, 1491-1498 (1997).

141. Winters, J. A. \& Page, B. I. Oligarchy in the United States? Perspect. Polit. 7, 731-751 (2009).

142. Piketty, T. Brahmin left vs merchant right: rising inequality and the changing structure of political conflict, WID world working paper 7. L'École des Hautes Études en Sciences Sociales http://piketty.pse.ens.fr/files/ Piketty2018.pdf (2018).

143. Gilens, M. \& Page, B. I. Testing theories of American politics: elites, interest groups, and average citizens. Perspect. Polit. 12, 564-581 (2014).

144. Montalvo, J. G. \& Reynal-Querol, M. Ethnic polarization, potential conflict, and civil wars. Am. Econ. Rev. 95, 796-816 (2005).

145. Chua, A. Political Tribes: Group Instinct and the Fate of Nations (Penguin Books, 2019).

146. Brown, D. E. Human Universals (McGraw Hill, 1991).

147. Brewer, M. B. Ingroup identification and intergroup conflict. Soc. Identity Intergroup Confl. Confl. Reduct. 3, 17-41 (2001).

148. Fiske, S. T. What we know now about bias and intergroup conflict, the problem of the century. Curr. Dir. Psychol. Sci. 11, 123-128 (2002).

149. Allport, G. W. The Nature of Prejudice (Addison-Wesley, 1954).

150. Pettigrew, T. F. Intergroup contact theory. Annu. Rev. Psych. 49 65-85 (1998).

151. Stolle, D. \& Harell, A. Social capital and ethno-racial diversity: learning to trust in an immigrant society. Polit. Stud. 61, 42-66 (2013).

152. Sigelman, L. \& Welch, S. The contact hypothesis revisited: black-white interaction and positive racial attitudes. Soc. Forces 71, 781-795 (1993)

153. Boisjoly, J., Duncan, G. J., Kremer, M., Levy, D. M. \& Eccles, J. Empathy or antipathy? The impact of diversity. Am. Econ. Rev. 96, 1890-1905 (2006).

154. Merlino, L. P., Steinhardt, M. F. \& Wren-Lewis, L. More than just friends? School peers and adult interracial relationships. J. Labor Econ. 37, 663-713 (2019).

155. Dixon, J., Durrheim, K. \& Tredoux, C. Beyond the optimal contact strategy: a reality check for the contact hypothesis. Am. Psychol. 60, 697-711 (2005).

156. Herrmann, M. Population aging and economic development: anxieties and policy responses. J. Popul. Ageing 5, 23-46 (2012).

157. Musterd, S. \& Ostendorf, W. Urban Segregation and the Welfare State: Inequality and Exclusion in Western Cities (Routledge, 2013).

158. Kumlin, S. \& Rothstein, B. Making and breaking social capital: the impact of welfare-state institutions. Comp. Polit. Stud. 38, 339-365 (2005).

159. Hamilton, D. \& Darity, W. Jr. Can 'baby bonds' eliminate the racial wealth gap in putative post-racial America? Rev. Black Polit. Econ. 37, 207-216 (2010).

160. Chetty, R. Improving equality of opportunity: new insights from big data. Contemp. Econ. Policy 39, 7-41 (2021).

161. Western, B. \& Rosenfeld, J. Unions, norms, and the rise in US wage inequality. Am. Sociol. Rev. 76, 513-537 (2011).
162. Ortiz-Ospina, E., Beltekian, D. \& Roser, M. Trade and globalization. Our World in Data https://ourworldindata.org/trade-and-globalization (2018).

163. Fallows, J. \& Fallows, D. Our Towns: A 100,000-Mile Journey into the Heart of America (Vintage, 2018).

164. McChrystal, S. How a national service year can repair America. The Washington Post (14 November 2014).

165. Collier, P. Exodus: How Migration Is Changing Our World (Oxford Univ. Press, 2013).

166. Ager, P. \& Brückner, M. Cultural diversity and economic growth: evidence from the US during the age of mass migration. Eur. Econ. Rev. 64, 76-97 (2013).

167. Bove, V. \& Elia, L. Migration, diversity, and economic growth. World Dev. 89, 227-239 (2017).

168. Klein, E. Why We're Polarized (Simon and Schuster, 2020).

169. Guiso, L., Sapienza, P. \& Zingales, L. Does culture affect economic outcomes? J. Econ. Perspect. 20, 23-48 (2006)

170. Schulz, J. F., Bahrami-Rad, D., Beauchamp, J. P. \& Henrich, J. The church, intensive kinship, and global psychological variation. Science 366, aau5141 (2019).

171. Henrich, J. The Weirdest People in the World: How the West Became Psychologically Peculiar and Particularly Prosperous (Farrar, Straus and Giroux, 2020)

172. Baker, J. O., Martí, G., Braunstein, R., Whitehead, A. L. \& Yukich, G. Religion in the age of social distancing: how COVID-19 presents new directions for research. Soc. Relig. 81, 357-370 (2020).

173. Mitchell, J. American Awakening: Identity Politics and Other Afflictions of Our Time (Encounter Books, 2020).

174. McWhorter, J. The elect: the threat to a progressive America from anti-Black antiracists. Substack https://johnmcwhorter.substack.com/ p/the-elect-neoracists-posing-as-antiracists (2021).

175. Bellah, R. N. Civil religion in America. Daedalus 96, 1-21 (1967).

176. Dovidio, J. F., Kawakami, K. \& Gaertner, S. L. in Reducing Prejudice and Discrimination (ed. Oskamp, S.) 137-163 (Lawrence Erlbaum, 2000).

177. Richeson, J. A. \& Nussbaum, R. J. The impact of multiculturalism versus color-blindness on racial bias. J. Exp. Soc. Psychol. 40, 417-423 (2004).

178. Krugman, P. End This Depression Now! (WW Norton, 2012).

179. Papanicolas, I., Woskie, L. R. \& Jha, A. K. Health care spending in the United States and other high-income countries. JAMA 319 , 1024-1039 (2018)

180. Akitoby, B., Clements, B., Gupta, S. \& Inchauste, G. Public spending, voracity, and Wagner's law in developing countries. Eur. J. Polit. Econ. 22, 908-924 (2006).

181. Lamartina, S. \& Zaghini, A. Increasing public expenditure: Wagner's law in OECD countries. Ger. Econ. Rev. 12, 149-164 (2011).

182. Rodrik, D. Why do more open economies have bigger governments? J. Polit. Econ. 106, 997-1032 (1998).

183. Saez, E. \& Zucman, G. Progressive wealth taxation. Brookings https://www. brookings.edu/wp-content/uploads/2020/10/Saez-Zuchman-final-draft.pdf (2019).

184. Hauser, W. K. There's no escaping Hauser's law. The Wall Street Journal (26 November 2010).

185. Value added tax in Denmark: a guide for non-resident businesses. Price Waterhouse Coopers https://www.pwc.dk/da/publikationer/2017/pwcvalue-added-tax-in-denmark.pdf (2017).

186. Metcalf, G. E. Value-added taxation: a tax whose time has come? J. Econ. Perspect. 9, 121-140 (1995).

187. Kallis, G., Kerschner, C. \& Martinez-Alier, J. The economics of degrowth. Ecol. Econ. 84, 172-180 (2012).

188. Van den Bergh, J. C. J. M. \& Kallis, G. Growth, a-growth or degrowth to stay within planetary boundaries? J. Econ. Issues 46, 909-920 (2012).

189. Stevenson, B. \& Wolfers, J. Subjective well-being and income: is there any evidence of satiation? Am. Econ. Rev. 103, 598-604 (2013).

190. Ortiz-Ospina, E. Happiness and life satisfaction. Our World in Data https://ourworldindata.org/happiness-and-lifesatisfaction (2013).

191. Helliwell, J. F., Layard, R., \& Sachs, J. D. World happiness report 2018 World Happiness Report https://worldhappiness.report/ed/2018/ (2018).

192. Hendriks, M. Does migration increase happiness? It depends. Migration Policy Institute https://www.migrationpolicy.org/article/does-migrationincrease-happiness-it-depends (2018)

193. Jebb, A. T., Tay, L., Diener, E. \& Oishi, S. Happiness, income satiation and turning points around the world. Nat. Hum. Behav. 2, 33-38 (2018).

194. Layard, P. R. G. \& Layard, R. Happiness: Lessons from a New Science (Penguin, 2011)

195. Kahneman, D. \& Deaton, A. High income improves evaluation of life but not emotional well-being. Proc. Natl Acad. Sci. USA 107, 16489-16493 (2010)

196. Kaufman, S. B. Transcend: The New Science of Self-actualization (JP Tarcher/Perigee Books, 2020). 
197. Yang, A. The War on Normal People: The Truth about America's Disappearing Jobs and Why Universal Basic Income Is Our Future (Hachette, 2018).

198. Cowen, T. The Great Stagnation: How America Ate All the Low-Hanging Fruit of Modern History, Got Sick, and Will (Eventually) Feel Better: A Penguin eSpecial from Dutton (Penguin, 2011).

199. Roser, M. Economic growth. Our World in Data https://ourworldindata. org/economic-growth (2020).

200. World Economic Outlook, April 2020: The Great Lockdown, Technical Report (International Monetary Fund, 2020).

201. Real GDP forecast (indicator). OECD https://data.oecd.org/gdp/realgdp-forecast.htm (2020).

202. Budget and economic data. US CBO https://www.cbo.gov/data/budgeteconomic-data (2020).

203. CBO. An evaluation of CBO's past deficit and debt projections, technical report. Congress of the United States https://www.cbo.gov/publication/ 55234 (2019).

204. Atkinson, A.B., Hasell, J., Morelli, S. \& Roser, M. The chartbook of economic inequality. The chartbook of economic inequality https://www. chartbookofeconomicinequality.com/ (2017).

205. IMF. Household debt, loans and debt securities. IMF https://www.imf.org/ external/datamapper/HH_LS@GDD/ (2020).

206. Roser, M. Fertility rate. Our World in Data https://ourworldindata.org/ fertility-rate (2014)

207. Hannah Ritchie, M.R. \& Ortiz-Ospina, E. Suicide. Our World in Data https://ourworldindata.org/suicide (2015).

208. OECD. Trust in government. OECD https://www.oecd.org/gov/trustin-government.htm (2020)

209. Ortiz-Ospina, E. Trust. Our World in Data https://ourworldindata.org/ trust (2016).

\section{Acknowledgements}

The authors thank M. Boileau, M. Kimball, R. Langendorf, W. Eichhorst, T. Ippolito, M. Hegwood, R. Marshall, two anonymous reviewers, and participants in several classes and seminars for helpful comments on an earlier version of this manuscript. This work was funded by the University of Colorado Boulder and the Cooperative Institute for Research in Environmental Sciences (start-up grant to M.G.B.). The funders had no role in study design, data collection and analysis, decision to publish or preparation of the manuscript.

\section{Author contributions}

M.G.B. conceived the study and analysed the data. M.G.B., A.P., A.R.C., S.D.G. and S.V. wrote the paper.

\section{Competing interests}

The authors declare no competing interests.

\section{Additional information}

Supplementary information The online version contains supplementary material available at https://doi.org/10.1038/s41562-021-01229-y.

Correspondence should be addressed to Matthew G. Burgess.

Peer review information Nature Human Behaviour thanks Giorgos Kallis and the other, anonymous, reviewer(s) for their contribution to the peer review of this work.

Reprints and permissions information is available at www.nature.com/reprints.

Publisher's note Springer Nature remains neutral with regard to jurisdictional claims in published maps and institutional affiliations.

(C) Springer Nature Limited 2021 